\title{
Clarity and brilliance: antimony in colourless natron glass explored using Roman glass found in Britain
}

\author{
Sarah Paynter $^{1}$ (D) Caroline Jackson $^{2}$ (D) \\ Received: 16 June 2017 / Accepted: 25 December 2017 / Published online: 23 March 2018 \\ (C) The Author(s) 2018
}

\begin{abstract}
This paper discusses the development of Roman antimony decolourised natron glass, its dominance, and subsequent decline, using new trace element data for colourless glass found in Britain. Experimental glasses are used to investigate the influence of different proportions of raw materials (particularly the ratio of natron to calcium carbonate) on the resulting transparency or opacity of glass when antimony is added. Focusing on the 1st to 3rd centuries AD, the study has found that (1) There are chronological differences in antimony colourless glass compositions including (a) some early vessels have abnormally low calcium, aluminium and barium levels; (b) 1st/mid-2nd-century AD vessels in Britain may also contain up to 0.6 wt\% lead oxide whereas mid-2nd/3rd-century AD vessels contain less than $300 \mathrm{ppm}$, and (c) the antimony content tends to decline over time. (2) These developments can be linked to production and recycling practices; but trace elements suggest that all of these antimony colourless glasses share an origin, probably Egypt. (3) Crucially, production of experimental glasses illustrates the inherent suitability of a sodium-rich, calcium-poor base glass composition for making antimony colourless glass, as it readily dissolves added antimony; conversely lower-sodium, higher-calcium glasses start to form opacifying calcium-antimonate crystals with the same quantities of antimony. Thus, the sodium-rich, calcium-poor glass composition from Egypt was ideally suited for decolourising with antimony and formed a water-clear glass. The calcium-rich Syro-Palestine glasses were more easily opacified with antimony to make opaque glass, but were decolourised with manganese, not antimony.
\end{abstract}

Keywords Glass $\cdot$ Roman $\cdot$ Hellenistic $\cdot$ Antimony $\cdot$ Colourless $\cdot$ Analysis

\section{Introduction}

Colourless ancient glass is often seen as a pinnacle of quality and technical accomplishment because it is difficult to make, since even low levels of contaminants in the raw materials give glass a strong colour. Before the Roman period, this is reflected by the relatively rarity of colourless glass, and yet

Electronic supplementary material The online version of this article (https://doi.org/10.1007/s12520-017-0591-5) contains supplementary material, which is available to authorized users.

Sarah Paynter

sarah.paynter@historicengland.org.uk

Caroline Jackson

c.m.jackson@sheffield.ac.uk

1 Historic England, Fort Cumberland, Fort Cumberland Road, Eastney, Portsmouth PO4 9LD, UK

2 Department of Archaeology, University of Sheffield, Northgate House, West Street, Sheffield S1 4ET, UK large assemblages of colourless and nearly colourless glass are typical of many Roman archaeological sites. Once the technology had been mastered, colourless glass lent itself to display and decoration by cutting and engraving, much like the rock crystal it closely resembled.

This paper traces the development of antimony colourless natron glasses, using high quality glass from British consumption assemblages from the mid-1st century $\mathrm{AD}$ until well into the 3rd century AD, and places them in the context of Hellenistic antimony decolorised glasses. It also explores the influence of different raw materials and the base glass compositions on the resulting glass transparency or opacity. The glass analysed is from sites across Britain (Binchester, Colchester, Wroxeter, Lincoln, York, Chester, Gloucester, Canterbury, London, Winchester and Wilcote) (Fig. 1). This period represents the peak of antimony decolorised glass production and consumption in the ancient world. The major element compositions of these samples have been published previously in a series of studies involving the authors but are reproduced here for ease of reference. This paper presents new 


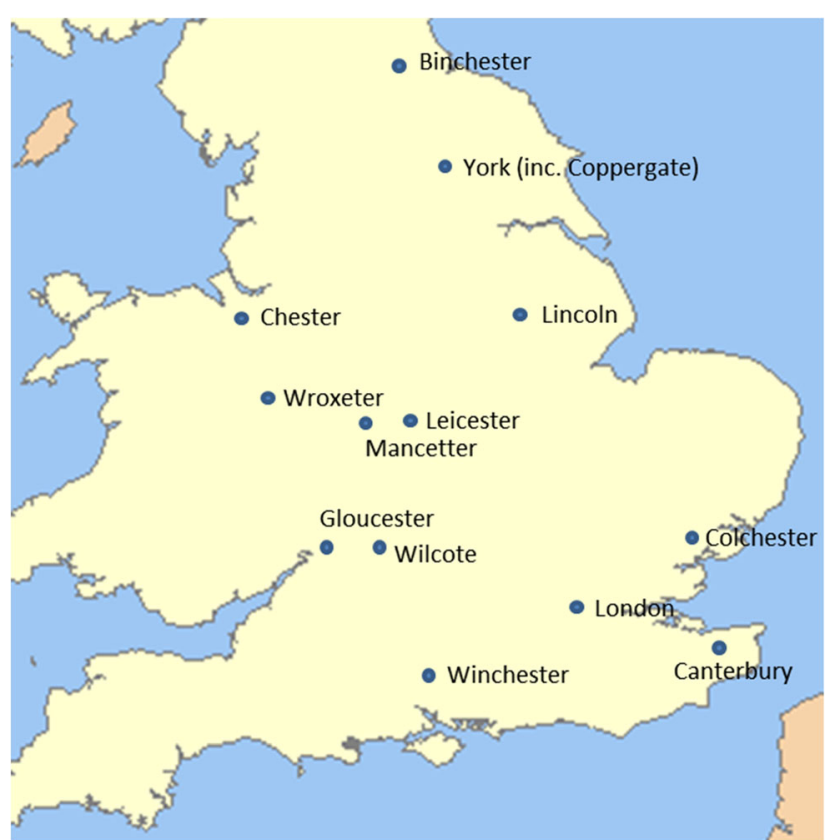

Fig. 1 Map of the UK showing the sites discussed in the text

trace element data, using LA-ICP-MS, and experimental work to explore how the Roman antimony colourless glass may have originated and how its composition changed over time in this northern province. New potential explanations for the changes in lead content are provided, centering on recycling.

\section{Background}

\section{Ancient natron glass production}

From around the 8th century $\mathrm{BC}$ a natron flux was commonly added to a silica source (Eichholz 1962; Jackson et al. 2016; Sayre and Smith 1961; Turner 1956) resulting in glasses with low levels of potassium, magnesium and phosphorus oxides. These natron glasses contain significant proportions of calcium (up to $10 \mathrm{wt} \%$ ), but as there is little calcium in the natron, the calcium oxide present is attributed to either shell, whether added separately or as an integral part of the sand used, or calcium-rich stone (see Turner 1956, 281).

Archaeological evidence for the production of early natron glasses has proved elusive, although possible Hellenistic production of glass has been reported from Rhodes and Beirut (Rehren et al. 2005; Triantafyllidis 2000, Kowatli et al. 2008). By the Roman period however, natron glass was being manufactured on a vast scale making use of tank furnaces. Primary glass production sites have been identified in Egypt and more recently in the Levant (Gorin-Rosen pers. com, Nenna et al. 1997; Nenna 2015), and there is evidence for large-scale glassmaking continuing into later periods in these regions, for example in Beirut, Lebanon, and at Jalame, Israel (Henderson 2013, 215-222). This confirms an account by Pliny the Elder, writing in the first century AD, who describes long-established manufactories in the Syro-Palestine area of the Eastern Mediterranean (NH XXXIV:65-66, Eichholz 1962). Although Pliny adds that glass was also produced in Italy, Gaul and Spain, no conclusive evidence for glassmaking has been found in these areas yet (Brems et al. 2012; Brems and Degryse 2014; Silvestri et al. 2006; Vallotto and Verità 2000).

The glass produced in these large furnaces was then transported in chunks to workshops to be shaped (Foy et al. 2000; Galili et al. 2015; Price and Cool 1991; Silvestri et al. 2008). Contemporary wrecks provide evidence for this trade in raw glass; cargoes also contained collections of broken glass for recycling (cullet) as well as finished glassware ready for use (Fontaine and Foy 2007; Thirion-Merle and Vichy 2007).

Numerous studies of Roman glass have identified only a small number of dominant transparent glass compositions. These include a manganese decolourised glass (high-Mn), an antimony decolourised glass ( $\mathrm{Sb}$ ) and a blue-green manganese glass (low-Mn), as well as recycled mixtures of these (Sb-Mn) (see references in Jackson and Paynter 2015, Table 3, Foy et al. 2003 and Gliozzo 2017). This evidence suggests that the market was dominated by a correspondingly small number of large production centres, but that the glass was widely consumed across the empire and beyond (Stern 1991), and recycled often. However, it is documented that the Levantine Belus glassmaking sand was collected by boat and shipped elsewhere (Flavius Josephus, Bellum Judaicum II, 10; Strabo XVI, 758), and Egyptian natron was also exported, so theoretically both could have been used to make chemically similar glass at other locations.

\section{Decolorisers and opacifiers}

The appearance of the 'base' natron glass could be changed using additives, and in Roman glasses this was often accomplished with the addition of metal-containing minerals. Lead antimonate was used for yellow (and in combination with copper $\left(\mathrm{Cu}^{2+}\right)$ blue to make green), and calcium antimonate for white (and in combination with copper $\left(\mathrm{Cu}^{2+}\right)$ or cobalt $\left(\mathrm{Co}^{2+}\right)$ for opaque blue) (Paynter et al. 2015 and references therein). In the $2 \mathrm{nd} / 1$ st centuries $\mathrm{BC}$, lead is also found in opaque blue and white glasses (Brill 1999; Licenziati and Calligaro 2015), even though lead is not necessary to produce the colour or opacity in those cases. Lead-rich opaque white glass continues to be used until around $60 \mathrm{AD}$ for selected objects, such as cameo or pillar-moulded vessels and plaques (with rare exceptions), however the majority of Roman opaque white glass is lead-free (Bimson and Freestone 1983; 
Henderson 1991; Mass et al. 1998; Mommsen et al. 1997; Whitehouse 1991 and 1997).

Antimony was also used to decolourise ancient glass, increasingly from the 7th century BC (Brill 1999; Sayre 1963; Gliozzo 2017), but was not the only decoloriser used in the ancient world; around the beginning of the 2 nd century BC manganese $(\mathrm{Mn})$ decolourised glass is increasingly found. Reade and Privat (2016) describe a possible Aegean antimony decolourising tradition co-existing with a Syro-Palestine centred manganese decolourising tradition at this time. By the 1st century $\mathrm{BC}$ manganese decolourised glass is widespread, and is used both in monochrome and polychrome objects (for example Bertini et al. 2011; Gliozzo 2017; Sayre 1963; Venclová et al. 2015). A little later, in the 1st century $\mathrm{AD}$, antimony $(\mathrm{Sb})$ colourless glass becomes very common, thus both decolorisers were in use in the Roman period (Brill 1999; Jackson and Paynter 2015).

\section{Production locations for Roman colourless glass}

For the Roman period, antimony ( $\mathrm{Sb}$ ) decolourised glass has been linked with Egypt (although as yet the Western Mediterranean cannot be excluded (Group 4, Thirion-Merle and Vichy 2007)). For example Barag (1987) highlights the price edict of Diocletian at the beginning of the 4th century $\mathrm{AD}$, which describes colourless glass as Alexandrian. Similarly, Nenna, Picon, Vichy and Thirion-Merle point out that some glass from production sites in the Wadi Natrun, Egypt, is very close in composition to the Roman antimony colourless glass composition (Picon et al. 2008; Vichy 2000; Thirion-Merle et al. 2002-3; Nenna et al. 2005; see also Gliozzo 2017; Jackson and Paynter 2015).
In contrast manganese decolourised glass (high-Mn), and a variety of blue-green or aqua glasses that also contain some manganese (low-Mn), have been associated with SyroPalestine production, making use of the famous Belus sand (for example Group 3, Foy et al. 2003; Jackson and Paynter 2015; Group CL2, Silvestri 2008; Thirion-Merle and Vichy 2007). This is supported by Pliny who mentions the long-lived glassmaking tradition in this area, and the Diocletian edict, which describes blue-green glass as Judean (Barag 1987; and summary of text sources by Gliozzo 2017).

The use of different decolorisers in the two primary production locations is of significance. To date, the primary focus of research into these decolorisers has tended to be on identifying potential sources of these minerals available in different regions, which may have influenced the glassmakers' choice of decolouriser (e.g. Shortland 2002). However, each region also used slightly different proportions of glassmaking raw materials when making natron glass, and different sand sources, producing base glasses of slightly different compositions. These differences are important for the choice of decoloriser in the glass and this forms the basis of the experimental work reported later in this paper.

\section{Development of antimony decolourised glass in the 1st millennium BC}

The use of antimony as a decolouriser in the 1st millennium $\mathrm{BC}$ is nearly always in natron glass (Table 1), with a few exceptions (such as the Neoassyrian plaques from Nimrud, which are made from plant ash glass (Brill 1978)). These early antimony colourless glasses were high status objects, such as Achaemenid bowls, Hellenistic colourless and gold-glass vessels, and gilded or painted glass inlays or plaques from

Table 1 Compositions of 1st- millennium BC antimony colourless glass from Brill (1978), Ignatiadou (2000) and Foy et al. (2004), wt\% oxides, nd = not detected, one sample unless otherwise indicated

\begin{tabular}{|c|c|c|c|c|c|c|c|c|c|c|c|c|}
\hline Site & Date & $\mathrm{SiO}_{2}$ & $\mathrm{Na}_{2} \mathrm{O}$ & $\mathrm{CaO}$ & $\mathrm{K}_{2} \mathrm{O}$ & $\mathrm{MgO}$ & $\mathrm{Al}_{2} \mathrm{O}_{3}$ & $\mathrm{Fe}_{2} \mathrm{O}_{3}$ & $\mathrm{TiO}_{2}$ & $\mathrm{MnO}$ & $\mathrm{PbO}$ & $\mathrm{Sb}_{2} \mathrm{O}_{3}$ \\
\hline Sardis, Turkey & $\sim 7$ th/6th C BC & 71.3 & 18.4 & 6.97 & 0.23 & 0.45 & 0.41 & 0.29 & 0.1 & 0.06 & 0.02 & 1.41 \\
\hline Phidias's workshop, Greece & 5th $\mathrm{C} \mathrm{BC}$ & 69.1 & 18.5 & 6.68 & 0.61 & 0.93 & 0.82 & 0.75 & 0.08 & 0.04 & 0.005 & 2.22 \\
\hline Persepolis, Iran & $\sim 5$ th $\mathrm{C} \mathrm{BC}$ & 69.07 & 18.05 & 6.68 & 0.61 & 0.93 & 0.82 & 0.75 & 0.08 & 0.04 & 0.005 & 2.22 \\
\hline \multirow[t]{2}{*}{ Vergina, Macedonia } & 4th C BC $(n=5)$ & 65.3 & 18.7 & 7.9 & 0.68 & 0.57 & 2.38 & 0.67 & 0.15 & 0.07 & 1.42 & 1.46 \\
\hline & St.Dev & 2.24 & 1.19 & 1.09 & 0.06 & 0.14 & 0.14 & 0.09 & 0 & 0.01 & 0.18 & 0.64 \\
\hline \multirow[t]{3}{*}{ Pydna, Macedonia } & Late 4th/early 3rd C BC & 67.29 & 18.59 & 7.14 & 1.36 & 0.61 & 1.63 & 0.48 & nd & 0.013 & nd & 1.81 \\
\hline & & 67.06 & 17.98 & 7.17 & 1.28 & 0.62 & 1.60 & 0.50 & nd & 0.013 & 0.121 & 1.81 \\
\hline & & 70.37 & 19.97 & 6.53 & 0.76 & 0.68 & 1.63 & 0.63 & nd & 0.011 & nd & 1.43 \\
\hline \multirow[t]{2}{*}{ Rhodes } & $\sim 3 \mathrm{rd} / 2$ nd C BC $(n=5)$ & 69.5 & 16.4 & 8.56 & 0.92 & 0.60 & 1.98 & 0.37 & 0.09 & 0.05 & 0.003 & 0.64 \\
\hline & St.Dev & 1.73 & 1.1 & 1.25 & 0.41 & 0.09 & 0.2 & 0.06 & 0.01 & 0.35 & 0 & 0.63 \\
\hline Lefkada Tomb, Macedonia & $\sim 300 \mathrm{BC}$ & 66.6 & 18.6 & 8.79 & 0.60 & 0.70 & 2.26 & 1.09 & 0.10 & 0.005 & 0.01 & 0.90 \\
\hline Carthage, Tunisia & Late Hellenistic & 74.46 & 17.91 & 3.96 & 0.45 & 0.6 & 1.12 & 0.33 & 0.064 & 0.00 & 3.81 & 1.32 \\
\hline Marseille, France & Late Hellenistic & 74.85 & 18.09 & 4.21 & 0.67 & 0.5 & 1.12 & 0.46 & 0.086 & 0.00 & 2.78 & 1.02 \\
\hline
\end{tabular}


Greece, Turkey and Iraq (Brill 1978; Brill and Barnes 1994; Foy et al. 2004; Ignatiadou 2000; Sayre 1963). (Later antique glasses are not discussed here but see Gliozzo 2017.)

Table 1 shows published antimony colourless glass compositions of the 1st-millennium $\mathrm{BC}$, highlighting changes through time. Three compositional traits relating to their base glass compositions are emphasised:

a) The calcium content increases slightly over time until the late Hellenistic period and, with the exception of the late Hellenistic examples, all the glasses contain more than $6 \mathrm{wt} \%$ of calcium oxide.

b) The alumina content, derived from impurities in quartz pebbles or sand, increases around the 4th century BC potentially reflecting a change in the silica source.

c) The antimony content generally increases with the ratio of sodium to calcium, so the glasses with the lowest sodium and highest calcium contents contain the least $(<1 \mathrm{wt} \%)$ antimony oxide. There is a good correlation where all other factors (the glass composition and presumably conditions for making the glass) are comparable; the correlation is therefore strong for contemporary material from one site e.g. Rhodes (reviewer's observation). The late Hellenistic examples do not sit on the same trend line as the other glasses however, as these contain higher levels of silica and lead oxide, making comparisons less meaningful.

Amongst the glasses in Table 1, the late Hellenistic antimony colourless glasses are distinctive. For around the 1st century $\mathrm{BC}$, there are very few analyses of antimony colourless glass, with the exception of these two vessels reported by Foy et al. (2004), although these are not closely dated. These antimonydecolorised glasses are markedly different from the preceding ones. They have low levels of aluminium (less than $1.5 \mathrm{wt} \%$ ) and calcium oxides (less than $5 \mathrm{wt} \%$ ), less than $100 \mathrm{ppm}$ barium (Foy et al. 2004, Lot A group, Fig. 4 (Marseilles)) (Table 1) and are more silica-rich; both of these examples also contain significant amounts of lead oxide.

Some of these late Hellenistic compositional traits continue into the 1st century AD in specific high quality vessel forms (see later in this paper). However, in assemblages from much of continental Europe, by the mid-1st century AD, this is replaced by antimony glass with nearer $6 \mathrm{wt} \%$ calcium oxide, $2 \mathrm{wt} \%$ aluminium oxide and $130 \mathrm{ppm}$ barium, and less than $0.6 \mathrm{wt} \%$ lead oxide. Lead disappears altogether from antimony colourless glass later in the 2nd century AD (Baxter et al. 2005; Paynter 2006; Silvestri et al. 2008).

\section{Material and analytical methods}

The new data presented here are for excavated fragments of Roman colourless glass of 1 st- to 3rd-century AD forms from sites in Britain. These include cast vessels (c.AD70-160), cylindrical cups (c.AD160-210), wheel-cut beakers (c.AD80175), facet-cut vessels (c.AD70-160) and later convex bowls (mid-2nd to 3rd centuries AD) (Baxter et al. 2005; Cool and Jackson 2004; Cool and Price 1995; Price and Cottam 1998; Price and Worrell 2010; and the unpublished report for the Lincoln glass by Price, Cottam and Worrell). The identification of vessel type is essential for understanding how different glass compositions were used, and for providing a date range for the glass compositions (Heyworth et al. 1990; Jackson 2005; Mortimer and Baxter 1996; Paynter 2006). The vessel types and date ranges are given in Table 2.

The major element data (Table 2) have been published previously for all of the samples but are reproduced here for convenience with an increased number of elements (see Jackson et al. (2003) and Baxter et al. (2005) for Colchester, Wroxeter, Lincoln, York, Chester, Canterbury, London, Winchester and Wilcote, and Paynter (2006) for the other samples from Colchester and Lincoln and Binchester). All major elements were analysed in solution using inductively coupled plasma spectrometry using the NERC facility located at Royal Holloway, University of London (see supplementary data).

None of the trace element data in Table 2 have been published previously. Some trace elements have been previously published for samples labelled BIN, COL or LIN, but these were re-analysed with ICPMS to ensure comparability with the others, and because 11 further elements were sought. The trace elements were determined using a CETAC LSX-100 laser ablation system at Imperial College, Ascot. Sample preparation, instrument parameters, protocols, detection levels and figures for precision and accuracy of the data are reported in Jackson and Nicholson (2010) and in the supplementary data. The data show a good correspondence with the consensus values for NIST 612, given in Pearce et al. (1997). Thirty replicates of NIST 612 over the run showed a precision better than $10 \%$.

The experimental melts were produced using laboratory grade sodium bicarbonate, calcium carbonate and L30A glassmaking sand with additions of antimony oxide as appropriate (Table 4). The batches were heated in mullite-rich crucibles to $1100{ }^{\circ} \mathrm{C}$ for $2 \mathrm{~h}$ in a silicon carbide electron furnace and allowed to cool slowly according to the methods of Jackson and Smedley (2004) and Foster and Jackson (2005) and see supplementary data. These were analysed using an FEI Inspect SEM and Oxford Instruments EDS system, with operating conditions of $25 \mathrm{kV}$ and $\sim 1.5 \mathrm{nA}$. Corning standards were analysed to ensure precision and accuracy. 


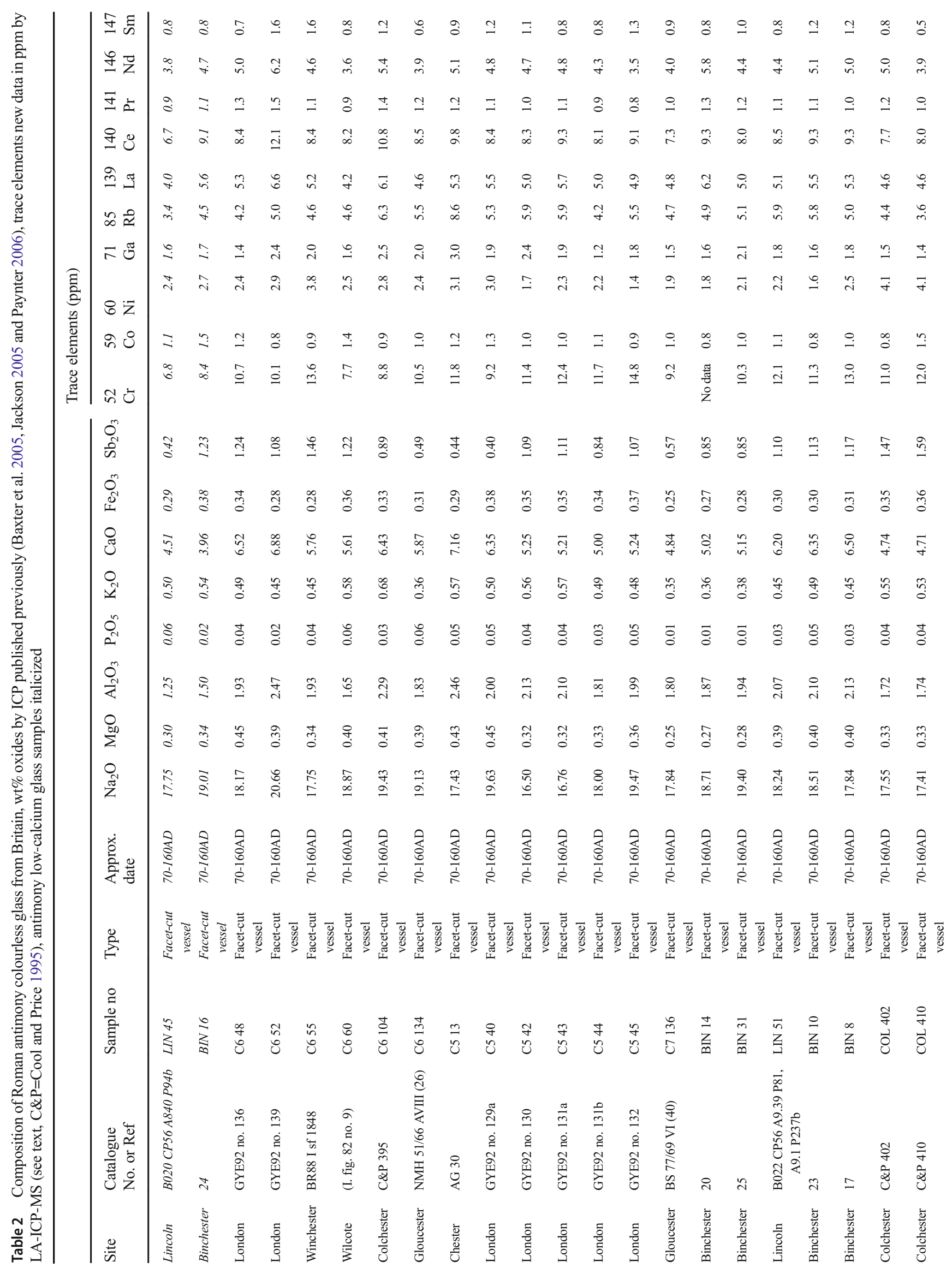




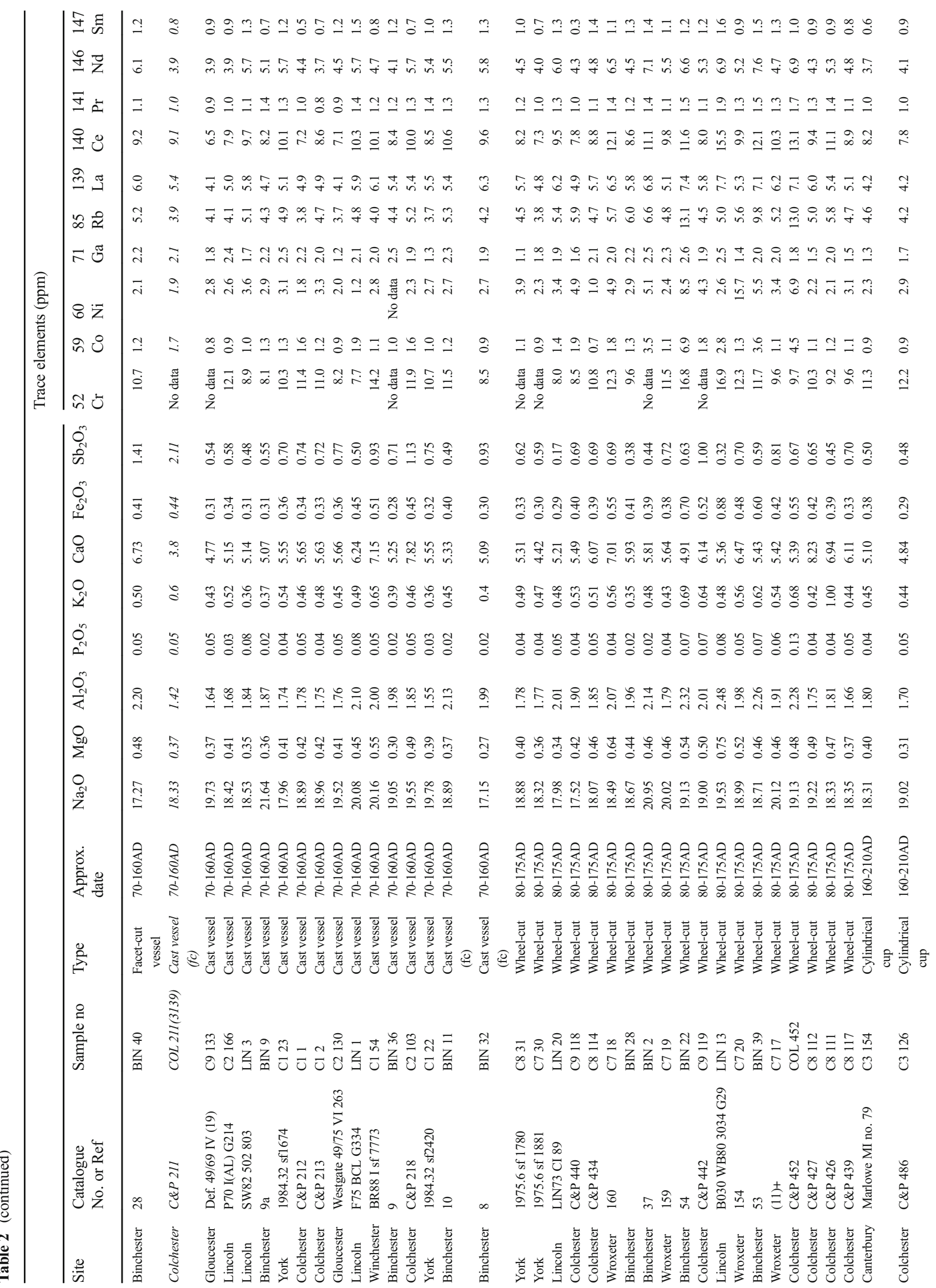




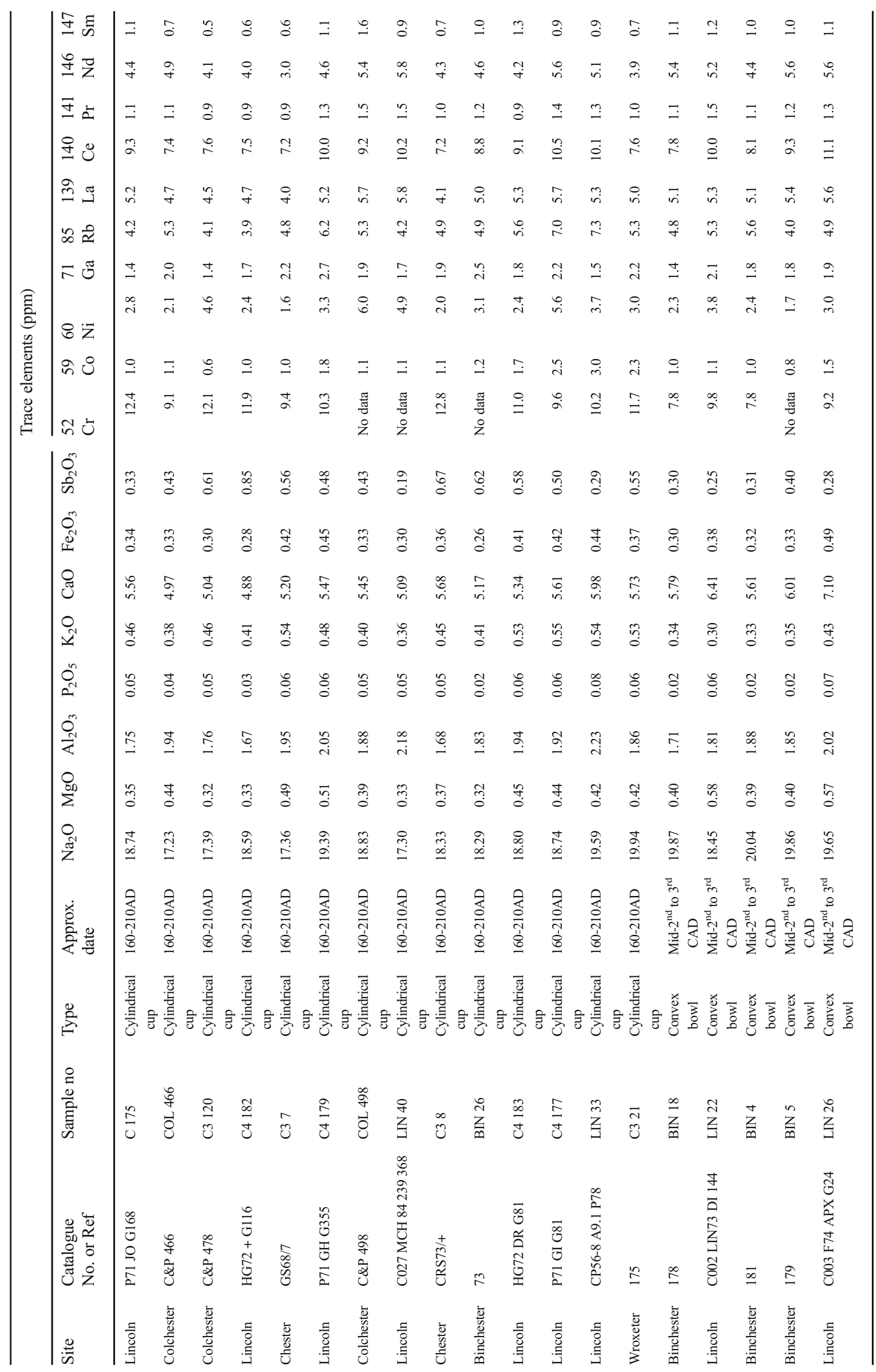




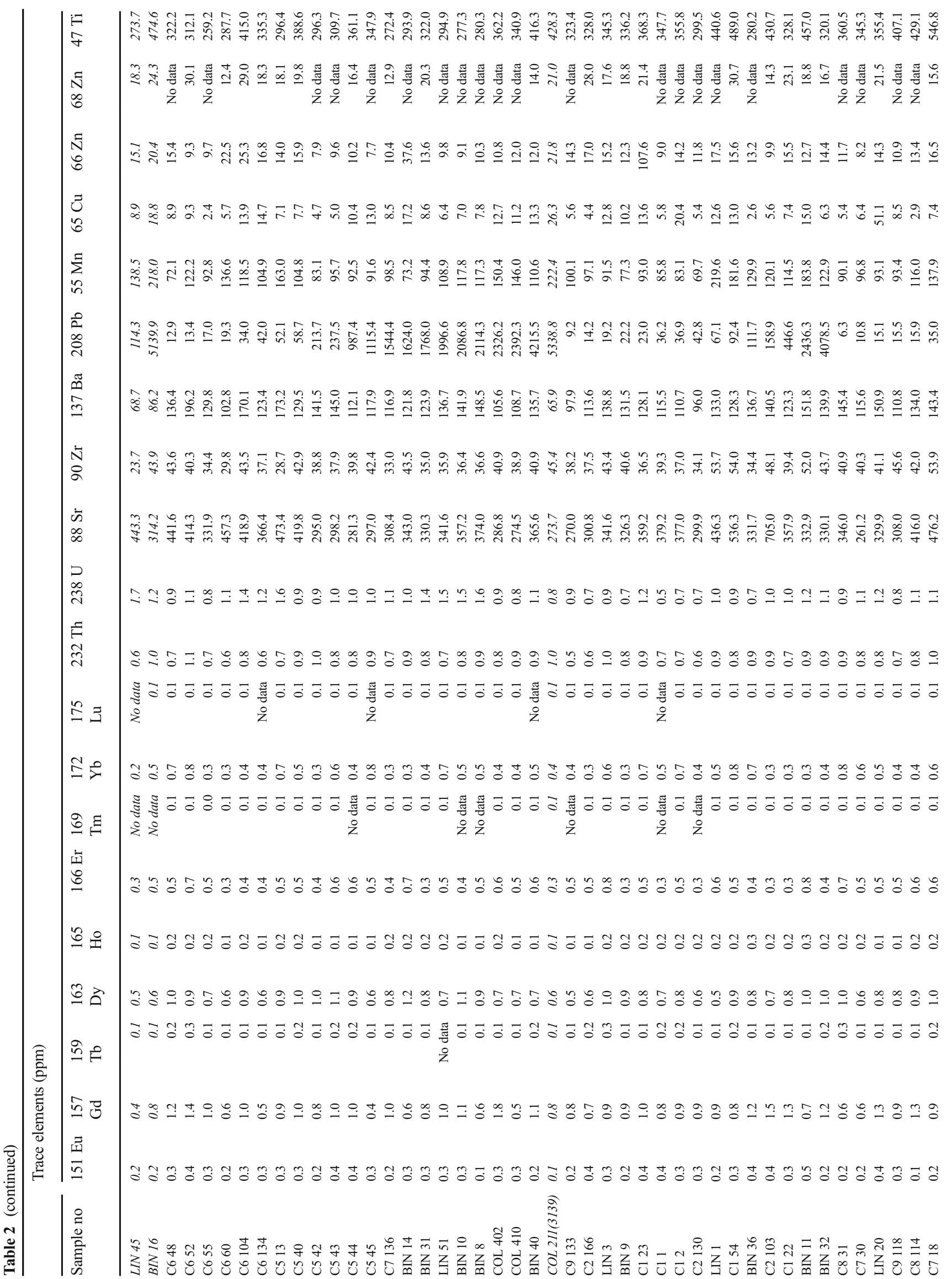




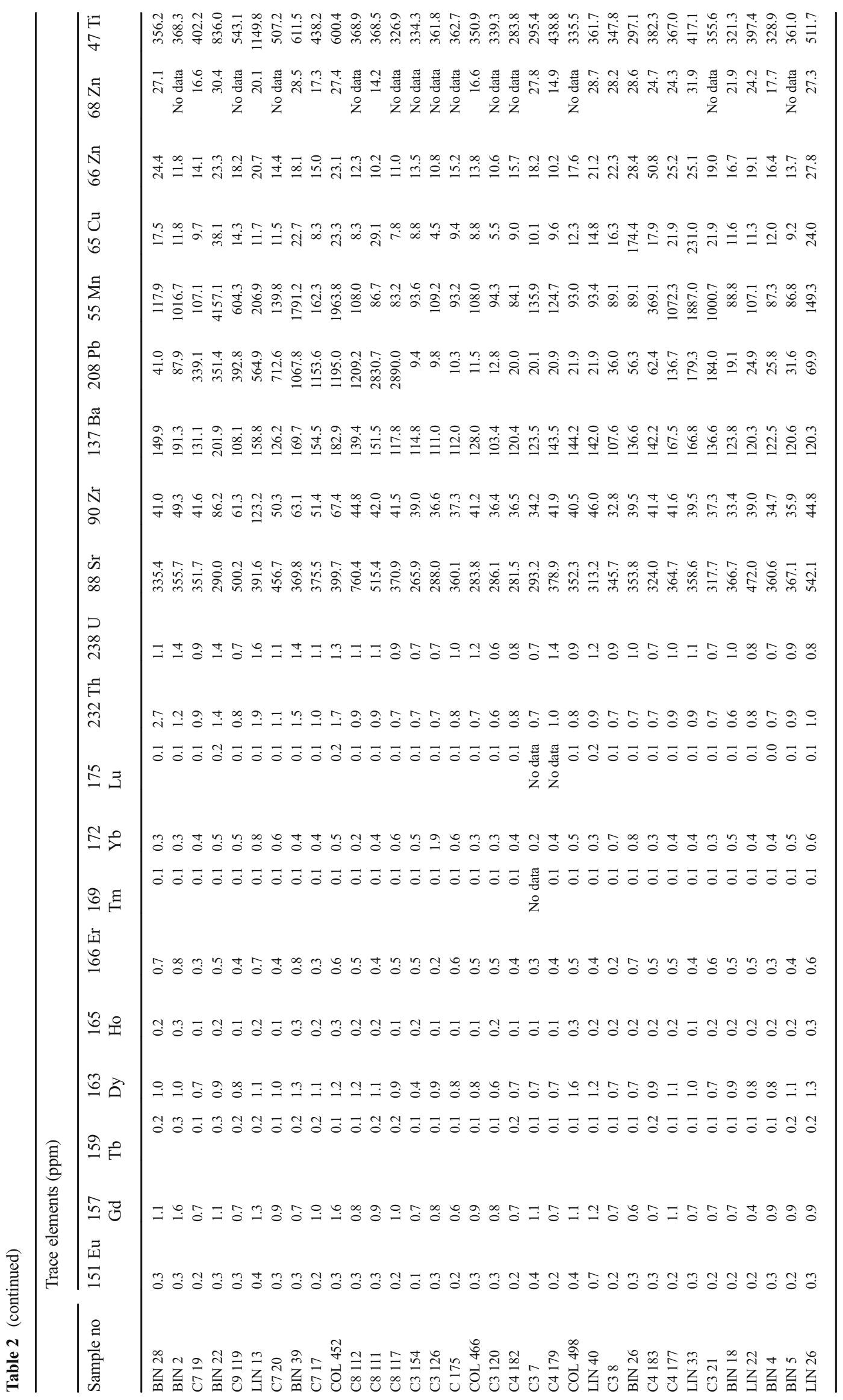


Table 3 Compositional data for three atypical 1st-century AD low-calcium antimony colourless vessels compared to typical Roman antimony colourless glass. ('Typical' Roman glass calculated from average of 47 examples, excluding those containing more than $300 \mathrm{ppm} \mathrm{Pb}, 0.15 \mathrm{wt} \%$ $\mathrm{MnO}$ or $0.2 \mathrm{wt} \% \mathrm{TiO}_{2}$ from Table 2 dataset), 'Roman with $\mathrm{Pb}$ ' average of samples with $>300 \mathrm{ppm}$ lead), wt $\%$ oxide except Ba ppm, nm-not measured

\begin{tabular}{llrrrrrrrrrrrr}
\hline Date & & $\mathrm{SiO}_{2}$ & $\mathrm{Na}_{2} \mathrm{O}$ & $\mathrm{CaO}$ & $\mathrm{K}_{2} \mathrm{O}$ & $\mathrm{MgO}$ & $\mathrm{Al}_{2} \mathrm{O}_{3}$ & $\mathrm{Fe}_{2} \mathrm{O}_{3}$ & $\mathrm{TiO}_{2}$ & $\mathrm{MnO}^{2} \mathrm{PbO}^{2} \mathrm{Sb}_{2} \mathrm{O}_{3}$ & $\mathrm{Ba}^{2}$ \\
\hline Low-Ca & LIN 45 & 72.42 & 19.01 & 3.96 & 0.54 & 0.34 & 1.50 & 0.38 & 0.04 & 0.02 & 0.55 & 1.23 & 86.19 \\
& BIN 16 & 74.87 & 17.75 & 4.51 & 0.50 & 0.30 & 1.25 & 0.29 & 0.03 & 0.02 & 0.01 & 0.41 & 68.68 \\
& $\mathrm{COL211}$ & 72.21 & 18.33 & 3.80 & 0.60 & 0.37 & 1.42 & 0.44 & 0.06 & 0.03 & 0.58 & 2.10 & 65.89 \\
Other-'Typical' Roman & $(n=47)$ & 71.62 & 18.77 & 5.71 & 0.46 & 0.41 & 1.91 & 0.35 & 0.02 & 0.00 & 0.005 & 0.60 & 131.18 \\
& St.Dev & 1.63 & 1.08 & 0.73 & 0.08 & 0.07 & 0.19 & 0.06 & 0.01 & 0.01 & 0.005 & 0.32 & 21.24 \\
Roman with Pb & (n=25) & 71.56 & 18.66 & 5.56 & 0.50 & 0.41 & 1.93 & 0.41 & 0.07 & 0.05 & 0.21 & 0.92 & 132.50 \\
& St.Dev & 1.32 & 0.80 & 0.88 & 0.09 & 0.11 & 0.21 & 0.15 & 0.03 & 0.11 & 0.15 & 0.34 & 28.40 \\
\hline
\end{tabular}

\section{Results}

There are several chronological trends observed in the compositions of the antimony colourless glass analysed here.

1. Some of the earliest vessels, from the 1 st to mid-2nd century $\mathrm{AD}$, have the same low-calcium base composition as late Hellenistic antimony colourless vessels (reported by Foy et al. 2004). They contain less calcium $(\sim 4 \mathrm{wt} \%)$ and aluminium oxides $(\sim 1.4 \mathrm{wt} \%)$, and barium $(\sim 70 \mathrm{ppm})$ than the rest (Table 3). Trace element data for 3 of these are presented (Table 2): BIN16 from a context dated to 90-95/100 AD, LIN45 (one of the earliest variants of facet-cut beaker with rare jigsaw facets) and COL211 from a context dated to 65/80-150 AD.

2. The lead content decreases through time (Fig. 2). Some of the 1st-century AD antimony colourless glass analysed here contains up to $0.6 \mathrm{wt} \%$ of lead oxide (Fig. 2). The highest levels are in the lower-calcium glasses, described

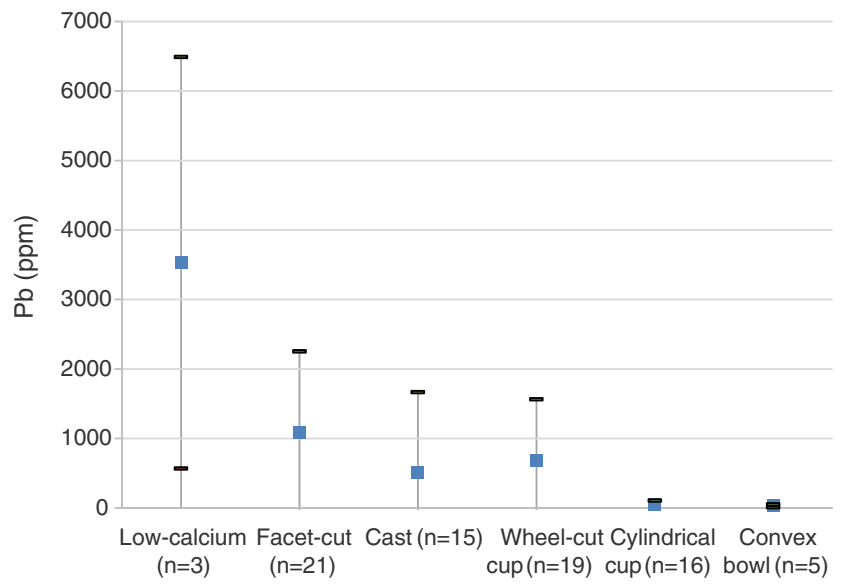

Fig. 2 Average lead content (ppm) of antimony colourless glass from Roman sites in Britain (data from Table 2), with one standard deviation shown by bars. Cast and facet-cut vessels (late 1st to mid-2nd century, with the low-calcium vessels likely to be earliest), wheel-cut cups (late 1st to 2nd), cylindrical cups (late 2 nd to mid-3rd), and convex facet-cut bowls (mid-2nd to 3rd). above (Table 3). For those glasses that do contain lead, there is a broad positive correlation between lead and antimony oxides. In contrast, the wares post-dating the mid-2nd century AD contain only traces of lead (less than $300 \mathrm{ppm}$ ), such as the cylindrical cups and the later variant of facet-cut bowl.

3. The amount of antimony present is high initially but gradually decreases towards the 4th-century AD (Fig. 3).

\section{Discussion}

\section{The base composition of antimony decolourised glass}

A further 17 samples with the lower-calcium composition, also facet-cut or the bases of cast wares, have been identified in previous studies of British antimony colourless glass (COL 222, 224, 225, 417, 209; LIN 49, 52 and BIN 24 in Paynter (2006); 10, 77, 81, 167, 168, 197 and 198 in Baxter et al. (2005)). These examples from Britain are all types of vessel dating to early in the Roman period. They

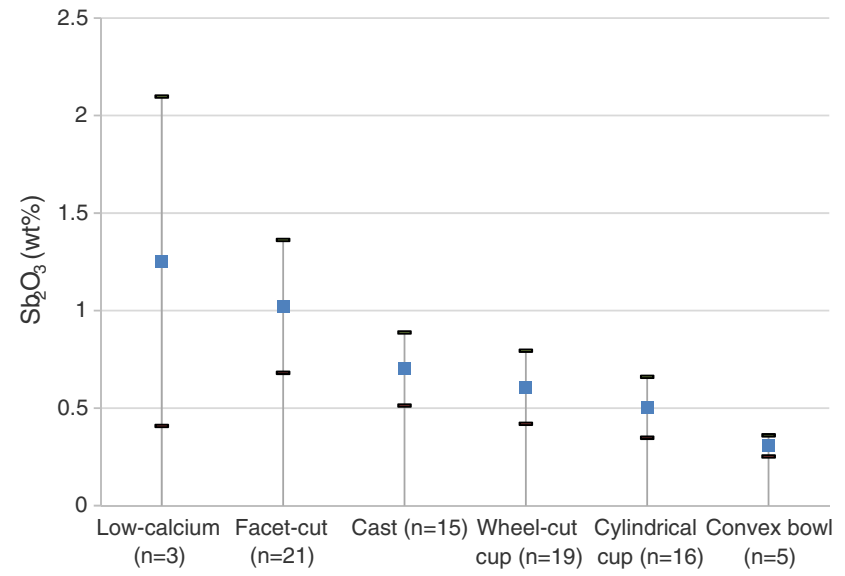

Fig. 3 Average antimony content (wt \% oxide) of the glass in Table 2 (from Paynter 2006, Baxter et al. 2005, Jackson 2005) with one standard deviation shown by bars. See Fig. 2 for key 
have the same base glass composition as the late Hellenistic antimony colourless vessels from Carthage and Marseille (Foy et al. 2004), so are likely to be a continuation of the late Hellenistic composition. More analyses of late Hellenistic antimony colourless glass are needed to explore this, but the low-calcium base composition appears to be characteristic of 1 st century BC/early 1st century $\mathrm{AD}$ antimony colourless glass, whereas the more typical Roman antimony colourless glass, still sodium-rich but with slightly more calcium oxide ( $\sim 5$ to $7 \mathrm{wt} \%$ ), becomes ubiquitous by the mid-1st century AD.

The lower-calcium base glass, found in earlier vessels, and the subsequent standard Roman antimony colourless glass have very similar trace (Fig. 4) element compositions, and so are probably related and originate from the same general region. The ratios of elements, such as barium and aluminium, are comparable suggesting similar mineral assemblages in both. The lower aluminium, and barium in the earlier glass reflects lower concentrations of minerals, such as feldspar, and so use of purer sand. The zirconium is mostly low, but with occasional outliers, which also seems to be a pattern in these antimony colourless glasses.

If these antimony colourless glasses share the same origins, then the slight differences in the base glass composition, from late Hellenistic through Roman, may be due to the heterogeneity of the sand source, with depth or across an area, resulting in subtle changes in the glass composition over time. Alternatively these glasses may be the products of different, but nearby, furnace sites. Pliny also describes the intentional addition of shell in glassmaking (Nat. Hist. XXXVI: 194), which could be used to increase the calcium (and strontium) content of the glass, necessary for glass stability, which may explain the increased levels of calcium in the later antimony colourless glasses.

The lead and antimony contents of the low-calcium samples from various British assemblages are plotted in Fig. 5b, and the range is similar to other facet-cut vessels from this assemblage.

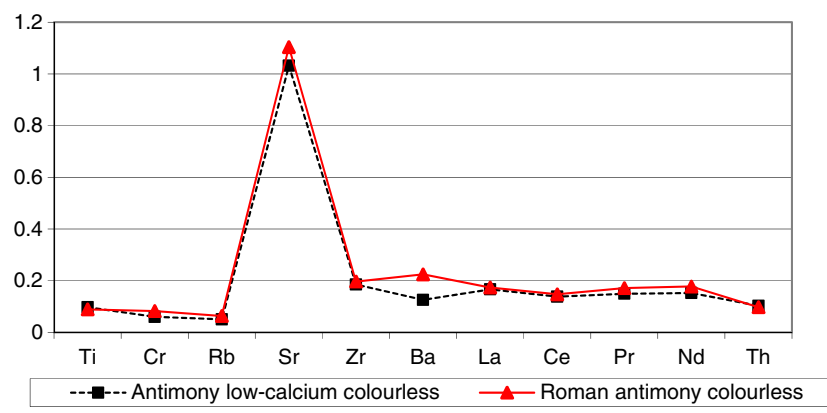

Fig. 4 Average trace element values (normalised against the earth's crust (Wedepohl 1995)) for the antimony low-calcium $(n=3)$ glasses and standard Roman antimony colourless $(n=47)$ glasses from this study, Table 2

\section{The origins of Roman antimony colourless glass}

In addition to contemporary literary accounts, archaeological evidence suggests a probable Egyptian origin for Roman antimony decolourised glass (as well as the earlier variant with low-calcium). Picon et al. (2008) analysed glass from several primary production sites in the Wadi Natrun, Egypt, with multiple phases of activity producing different types of glass, some of which are without close parallels elsewhere (Nenna 2015). Within these different compositions, it has been noted that the antimony decolourised glass from Beni Salama (Picon's composition wnc) is most comparable to standard Roman antimony glass, sodium-rich with low levels of calcium and aluminium oxides and zircon. Two samples from the same site (Picon's composition wnd) contain lead as well as antimony, and have unusually low levels of calcium oxide (1.6 wt\%), traits shared with late Hellenistic antimony colourless compositions. Use of the Beni Salama furnaces appears to span the end of the 2nd century $\mathrm{BC}$ to the beginning of the 3rd century AD (Nenna 2015).

a

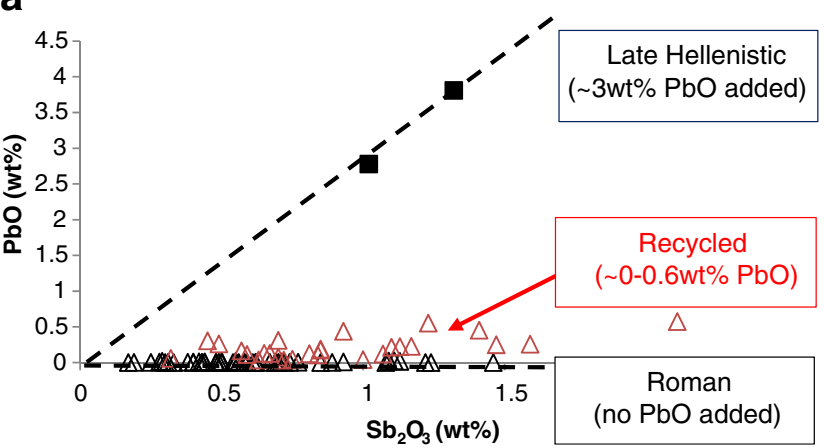

$\Delta$ Roman antimony colourless $\mathbf{D}$ Hellenistic antimony colourless

b

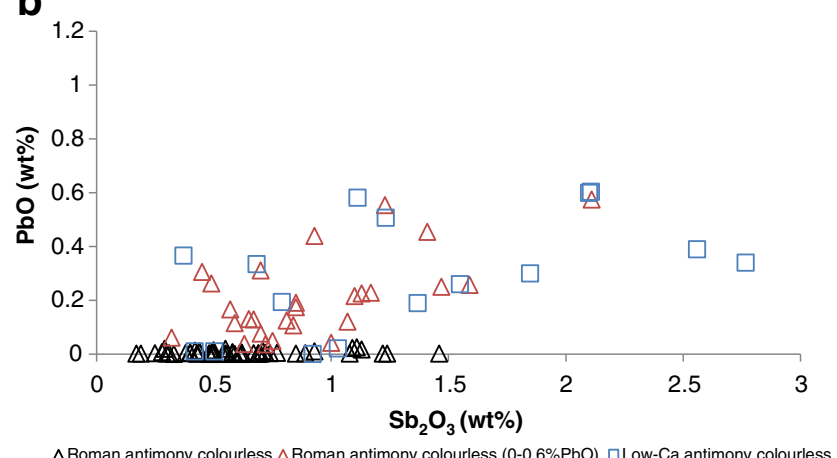

Fig. 5 a Dashed lines showing the high ratio of lead to antimony in late Hellenistic antimony colourless glass analysed to date (Foy et al. 2004), and absence of lead in most Roman antimony colourless glass from Britain (Table 2), with intermediate levels (up to $0.6 \mathrm{wt} \%$ ) in $1 \mathrm{st} / 2 \mathrm{nd}-$ century AD examples, potentially due to recycling. b Detail from Fig. 5a, showing the absence of lead in most Roman antimony colourless glass from Britain (Table 2), with intermediate levels (up to $0.6 \mathrm{wt} \%$ ) in 1st/ 2nd-century AD examples, potentially due to recycling; (low-Ca samples from other British studies also included - see text) 
In summary, some antimony colourless glass from around the 1 st century AD in Britain shows a particularly low-calcium, low-barium, low-aluminium composition. This composition appears to have its roots in the late Hellenistic period, but from the early 1 st century AD the standard Roman antimony colourless glass composition, which contains a little more calcium and aluminium, dominates Roman assemblages from Britain and beyond. There are similarities between the lowcalcium and standard compositions though, suggesting that they share a common origin, and present evidence connects them with Egypt. There is variation in the lead content however, and this is explored in the following section.

\section{Lead levels in Roman antimony colourless glass from Britain}

Some of the early 1 st- to 2nd-century colourless glasses from Britain contain lead oxide in concentrations up to $0.6 \mathrm{wt} \%$, whereas most of the Roman antimony colourless glass analysed here contains none (less than $300 \mathrm{ppm}$ ). The amounts vary greatly (Fig. 2), but even $0.6 \mathrm{wt} \%$ lead oxide is still unlikely to have had a noticeable effect on the glass properties, so intentional addition of lead seems unlikely at these levels.

Lead has previously been attributed to contamination in the antimony source used to decolorise some of the glass (e.g. Huisman et al. 2009; Paynter 2006). This contamination would derive from an antimony source which contained some lead gangue mineral, and this is a possibility as antimony ores are often sulphides and mineralogically complex mixtures (Anderson 2012; Foster and Jackson 2005; Gliozzo 2017; Paynter et al. 2015). However, the trace element analyses (Table 2) show that the antimony used for colourless glass was very 'clean'. The levels of barium, zinc, iron, copper, sulphur etc. are consistently very low; only lead is occasionally elevated. A clean source of antimony would have been essential to ensure that no colouring contaminants, in particular iron, were inadvertently added to the glass. Similarly, a clean source may have been necessary for opaque white glass for the same reasons. The likely source of this antimony is not known, but Transcaucasia has been suggested as a possible source of relatively pure antimony in the context of Bronze Age Egyptian glass colourants (Shortland 2002).

Therefore the lack of contaminants in the analysed antimony colourless glass, demonstrated by the trace element analyses, is more consistent with clean sources of lead and antimony being intentionally combined to prepare this glass additive, as opposed to the lead being an accidental contaminant. It is also significant that the ratio of lead to antimony oxides (a ratio of $\mathrm{PbO} / \mathrm{Sb}_{2} \mathrm{O}_{3}$ of between 2 and 4 ) is roughly similar in some late Hellenistic white, turquoise blue and cobalt blue glass (e.g. Licenziati and Calligaro 2015; Bimson and Freestone 1983; Freestone and Stapleton 2015; Mass et al. 1998) and in the small number of late Hellenistic antimony colourless glasses analysed to date (Foy et al. 2004). This implies a deliberate combining of lead and antimony in fixed proportions originating in the late Hellenistic period, and a link between the additives used for contemporary opaque glass (where the opacifier was effectively white and so impurities must be minimised) and the new type of antimony colourless glass. The role of the lead is explored experimentally later in this paper.

In the British antimony colourless glass assemblage studied here, the maximum amount of lead detected is only $0.6 \mathrm{wt} \%$ and a probable explanation for many of these samples is recycling. Around $3 \mathrm{wt} \%$ of lead oxide has been reported for the late Hellenistic antimony colourless glass analysed so far and subsequent recycling of this lead-bearing Hellenistic antimony glass could contribute small and changeable proportions of lead to each subsequent recycled batch. If only $15 \%$ of a batch was glass cullet containing $3 \mathrm{wt} \%$ lead oxide, it would contribute around $1700 \mathrm{ppm}$ lead to the batch overall, the highest concentrations observed in some of these early Roman glasses. Mixing of the lead-bearing and lead-free types of Sb colourless glass would have been most common in the 1 st century $\mathrm{AD}$ as fresh lead-free glass replaced the late Hellenistic lead-containing one. This would not only account for the wide range of lead levels (Figs. 5 and 6) found in each type of Sb colourless glass composition, but also why the lead disappears in the 2 nd century $\mathrm{AD}$, as very little glass from the 1 st centuries $\mathrm{BC} / \mathrm{AD}$ would still be circulating by this time (Fig. 2). This would imply that a fairly large proportion of the early facet-cut vessels, blown and cast, reaching Britain were made from recycled antimony colourless glass. It will be interesting therefore to compare this assemblage with others from the Mediterranean coast for example, where fresh glass may have been more readily available, to see if the proportion containing lead is similar.

There is further evidence to support recycling in the antimony colourless glasses analysed here, as some of the glass has also been contaminated with a small amount of the contemporary manganese decolourised glass during previous recycling (up to $0.2 \mathrm{wt} \%$, Table 2). This includes samples COL 452 and BIN 39, which contain elevated lead as well as manganese. This is detectable chemically but there is not enough contamination to make a difference to the appearance of the glass; it looks the same as the uncontaminated antimony decolorised glass.

\section{A chronological model}

In summary, the small number of antimony colourless glasses of the late Hellenistic period analysed to date contain around $3 \mathrm{wt} \%$ of lead oxide (eg. samples in Foy et al. 2004). At some point prior to the mid-1st century $\mathrm{AD}$, this practice may have changed and the same glass composition was made without lead (e.g. sample BIN16). Recycling of the lead-bearing and lead-free groups would lead to samples with intermediate lead 
levels (e.g. LIN45, COL 211). By the mid-1st century AD, large amounts of fresh, lead-free antimony colourless glass with a typical Roman composition (i.e. slightly higher in calcium and aluminium) are in use. During each of these transitions however, it is likely that some of the earlier glass would have still been circulating and valuable as a high quality recycling commodity for new colourless glass batches. During recycling these different antimony colourless glass types are likely to have been mixed, since they look the same and were all used for cast and blown cut-decorated vessels.

This chronological model of late Hellenistic through Roman antimony colourless glass production is summarised in Fig. 6: the differing concentrations of lead oxide, antimony oxide, lime and alumina are illustrated, from the left: first lower-calcium glass with added lead/antimony, then the same glass but with only antimony, and finally standard Roman antimony colourless glass.

\section{Supporting evidence for the chronological model from glass traded in Europe}

At this stage, this model is based on the few reported analyses of later Hellenistic glasses and so it is difficult to assess how typical Britain is, at the north-western edge of the Roman world, relative to areas where fresh antimony colourless glass may have been more readily available. However wreck cargoes provide some support for this chronological model of antimony colourless glass development. The Embiez wreck, of the later 2nd century AD, contained lumps of fresh glass as well as finished vessels and windows (Fontaine and Foy 2007;
Thirion-Merle and Vichy 2007). All of the fresh glass was of the standard antimony colourless composition and none of it contained lead, confirming that this source of fresh glass was lead-free at this time. The finished vessels were also antimony decolourised and were mostly lead-free, but three did contain some lead, and also manganese, consistent with the use of recycled glass for those items (Thirion-Merle and Vichy 2007).

The early 3rd-century AD Iulia Felix wreck, contained a barrel of fragments from glass bottles, plates and cups, collected for recycling (Silvestri et al. 2008; Ganio et al. 2012). Since this glass was presumably already old at the point it was collected, a range of dates may be represented, some potentially much earlier than the date the ship was wrecked. Much of the colourless glass was decolourised with antimony and most contained no lead, consistent with other assemblages of the later 2nd and 3rd centuries. There were only two exceptions (bottles $\mathrm{BO} 7$ and BO8 with $\sim 1000$ ppm lead), but both also contained less than $100 \mathrm{ppm}$ of barium, suggesting that these two samples may be older than many of the other fragments (Fig. 6).

Isotope analyses ( $\mathrm{Nd}$ and $\mathrm{Sr}$ ), which have been used to give an indication of the sand source for natron glass production, gave similar results for all of the Iulia Felix analysed antimony colourless glass samples on the ship, including those with low-calcium and barium levels. This suggests a common origin for all of the antimony colourless glass base compositions (low-calcium and standard Roman), regardless of chronological and compositional variation (Ganio et al. 2012), and supports the evidence presented here that the antimony colourless glasses from the late Hellenistic period to the 4th century $\mathrm{AD}$ originated in the same region, probably Egypt.

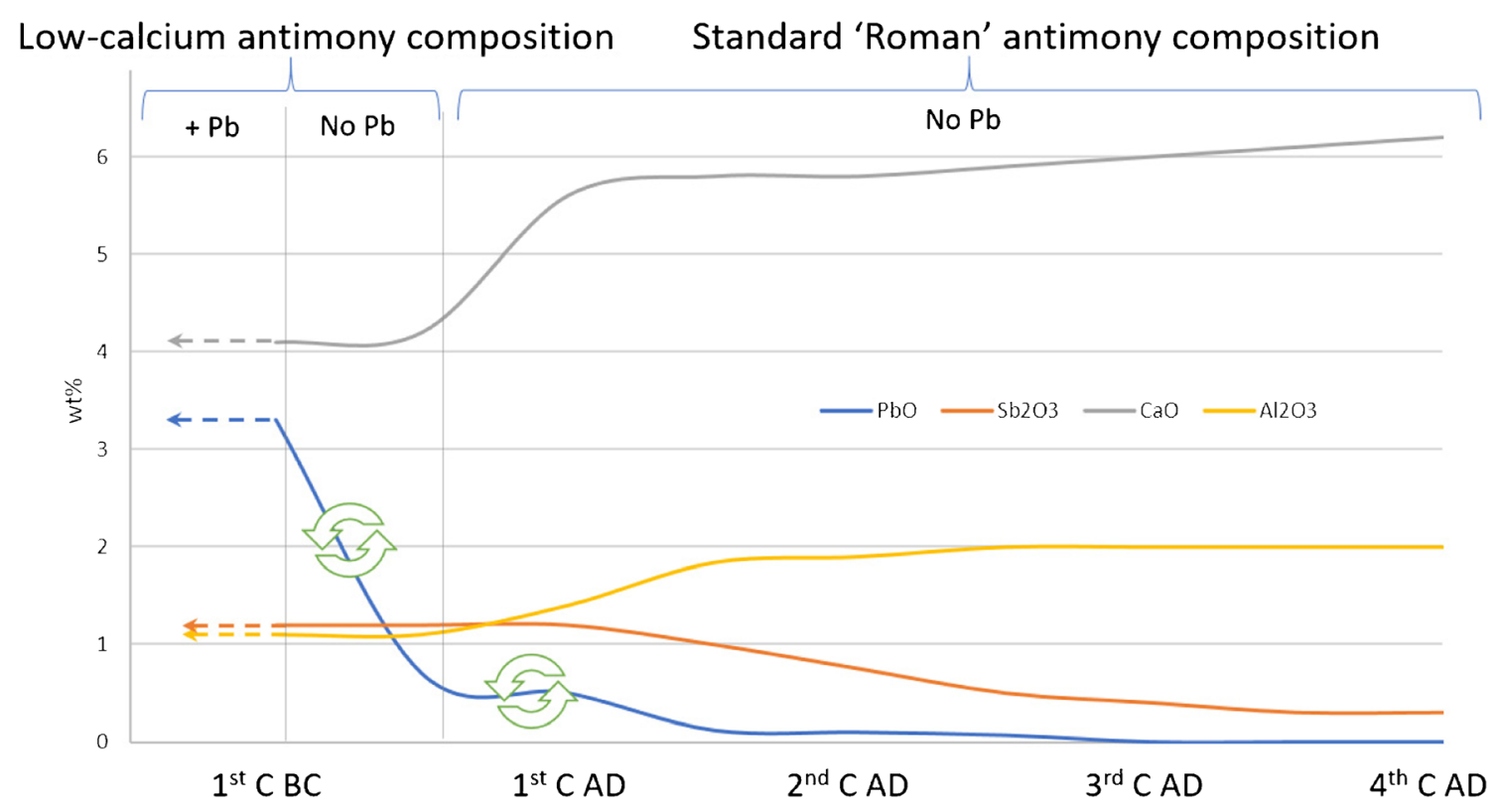

Fig. 6 Proposed broad chronological model for antimony colourless glass assemblages in the West. Late Hellenistic data from Foy et al. (2004), remainder from Table 2. Smoothed graph based on mean oxide levels and approximate vessel date ranges. Recycling symbols highlight intermediate lead levels due to possible mixing of glass types 
Fig. 7 Plot showing the sodium to calcium ratio and the manganese oxide content, indicative of different base glass compositions, for white opaque glass data, with 'White $(\mathrm{Pb})$ ' being lead-bearing examples (from Bimson and Freestone 1983; Freestone and Stapleton 2015; Mass et al. 1998) and for antimony colourless glass (lowcalcium and standard Roman from Table 2)

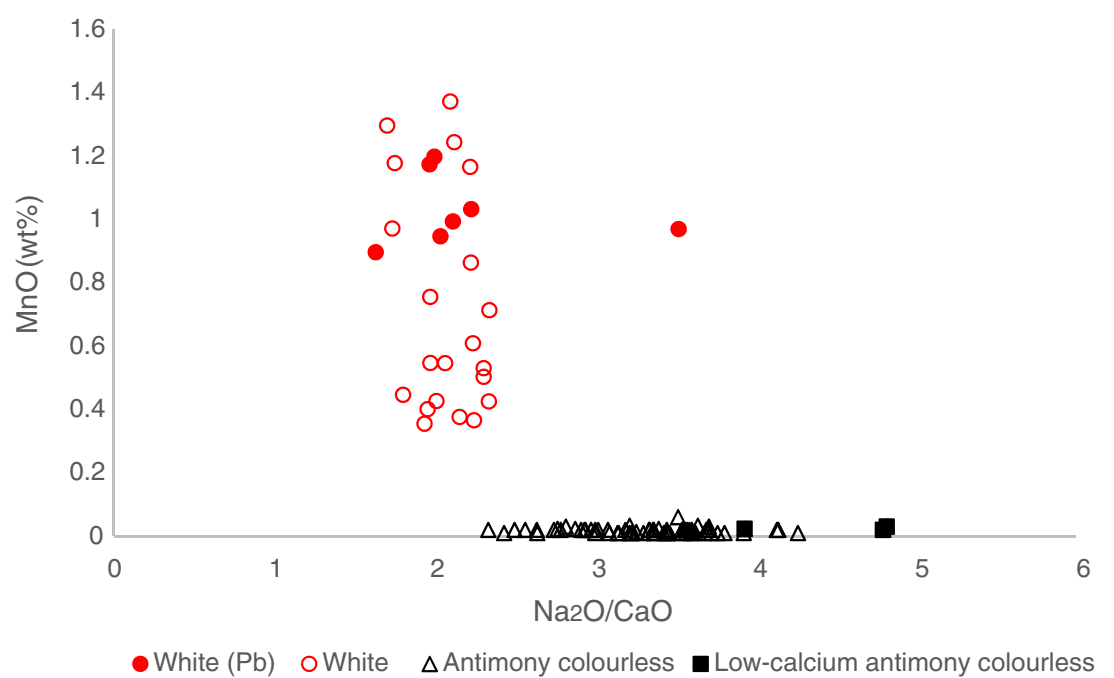

\section{The influence of base glass composition on antimony solubility}

The amount of antimony oxide dissolved in the glasses analysed here changes depending on the glass composition. Amongst the colourless Roman British glasses, the highest antimony concentrations are found in the 1st-century AD examples with especially low calcium contents (high sodium to calcium ratios). At the other end of the scale, the lowest levels of antimony are found in the glasses containing a low ratio of sodium to calcium. The same pattern is observed in 1stmillennium BC antimony colourless glasses (Table 1). These trends together suggest that antimony dissolves in larger amounts, decolourising more effectively, in glasses that are rich in sodium and low in calcium; but when antimony is added to a calcium-rich base glass, then white calcium antimonate will precipitate, causing the glass to become opaque.

\section{Comparing antimony colourless and opaque white glasses}

From a comparison of colourless and opaque white glasses of late Hellenistic / Roman date, it appears that glassmakers and glassworkers were aware of the importance of base glass composition on the behaviour of antimony. This comparison is particularly significant for the Roman period, as by then antimony colourless glass was as widely available as manganese decolourised glass, so any preference for one over the other is more likely to reflect a choice on the part of the glassworker (rather than the more limited availability of antimony decolourised glass prior to the mid-1st century AD).

The base glass preferred to make opaque white was the calcium-rich, manganese decolourised composition of probable Syro-Palestine origin (high Mn glass), indicated by the low ratio of sodium to calcium and presence of manganese (Fig. 7). The manganese decolouriser was added during primary production to provide a colourless base, whereas the antimony would have been added at a secondary workshop in order to make the glass opaque white.

In contrast sodium-rich, calcium-poor, Egyptian base glasses were used to make contemporary antimony decolourised glass (Fig. 7, Table 2). The antimony additive was added during primary production, and it dissolved causing the glass to decolourise. In this period, it appears the two base decolourisers were not perceived as interchangeable; manganese was preferred for decolourising calcium-rich Syro-Palestine glasses and antimony for Egyptian; and Egyptian glass (Fig. 7) was often avoided when making opaque white glass. As well as being made from different base glasses, opaque white glass typically contains more antimony (between 1.5 and $10 \mathrm{wt} \%$ ) than the contemporary colourless glass (less than $1.5 \mathrm{wt} \%$ antimony oxide).

\section{Experimental reproduction}

To demonstrate how the behaviour of antimony was influenced by the choice of base glasses, and the role of lead in the late Hellenistic glasses, experimental work was conducted to replicate two base Egyptian and Syro-Palestinian glass compositions, adding antimony oxide, and then lead oxide as well.

Table 4 Measured composition of experimental glasses, average of 3 analyses, wt $\%$ normalised, by SEM-EDS. Magnesium and iron oxides below detection $(0.1 \mathrm{wt} \%)$

\begin{tabular}{lccccccc}
\hline Comp. & $\mathrm{SiO}_{2}$ & $\mathrm{Na}_{2} \mathrm{O}$ & $\mathrm{CaO}$ & $\mathrm{K}_{2} \mathrm{O}$ & $\mathrm{Al}_{2} \mathrm{O}_{3}$ & $\mathrm{Sb}_{2} \mathrm{O}_{5}$ & $\mathrm{PbO}$ \\
\hline Syr-Pa & 71.80 & 14.34 & 7.84 & 0.59 & 2.25 & 3.17 & - \\
Egypt & 71.28 & 17.50 & 5.46 & 0.34 & 1.60 & 3.81 & - \\
Syr-Pa $+\mathrm{Pb}$ & 70.06 & 14.38 & 7.86 & 0.57 & 2.27 & 2.91 & 2.24 \\
Egypt $+\mathrm{Pb}$ & 67.37 & 18.52 & 5.95 & 0.58 & 1.76 & 3.47 & 1.87 \\
\hline
\end{tabular}


Fig. 8 The experimental Egyptian glass is transparent, sparkling and bubble-free (left) whereas the experimental SyroPalestine glass (right) is slightly duller, and contains opaque white crystals and bubbles (both with $3 \mathrm{wt} \%$ antimony oxide added)

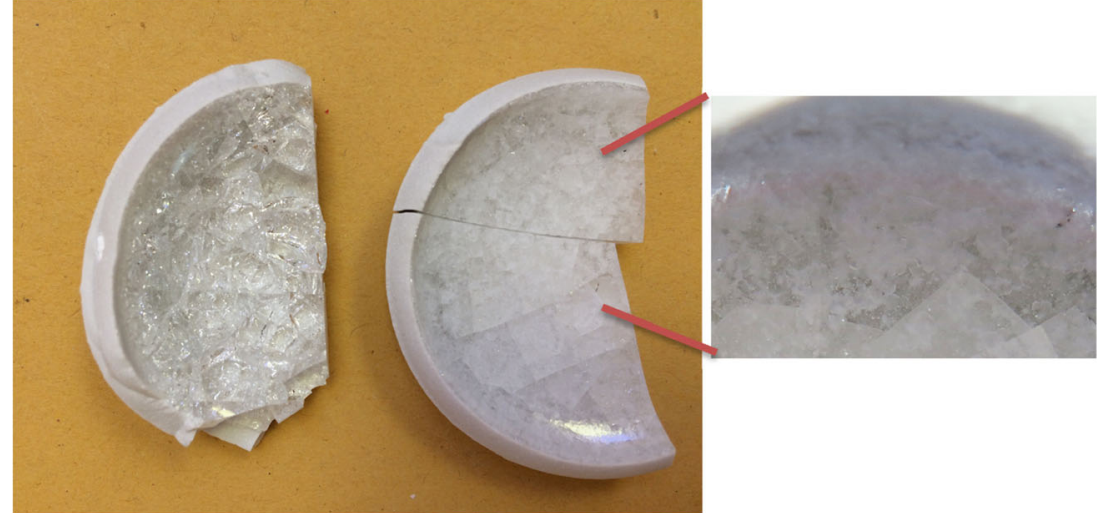

Experimental batches of glass of (a) the Syro-Palestinetype $\left(16 \mathrm{wt} \% \mathrm{Na}_{2} \mathrm{O}, 8.5 \mathrm{wt} \% \mathrm{CaO}, 2.5 \mathrm{wt} \% \mathrm{Al}_{2} \mathrm{O}_{3}, 73 \mathrm{wt} \%\right.$ $\mathrm{SiO}_{2}$ ) and (b) the Egyptian-type (20 wt $\% \mathrm{Na}_{2} \mathrm{O}, 5.5 \mathrm{wt} \% \mathrm{CaO}$, $1.5 \mathrm{wt} \% \mathrm{Al}_{2} \mathrm{O}_{3}, 73 \mathrm{wt} \% \mathrm{SiO}_{2}$ ) glasses were made. To each was added $3 \mathrm{wt} \%$ antimony oxide, which is around the maximum found in colourless glasses and the minimum found in opaque white glasses. The analysed composition is shown in Table 4. The photographs below show that the Syro-Palestine glass started to form white crystals whereas the Egyptian glass remains brilliant and transparent (Figs. 8 and 9). The higher calcium levels in the Syro-Palestine base glass caused the precipitation of opacifying calcium antimonate crystals, whereas the antimony has dissolved more readily in the calcium-poor Egyptian base glass under the same conditions, producing a brilliant, refined, colourless glass.

\section{The role of lead oxide}

The experiment was repeated adding lead oxide to the glass compositions, such that the bulk composition contained $2 \mathrm{wt} \%$ lead oxide (Table 4). The presence of lead oxide caused more rapid interaction with the crucible. In the Egyptian base glass, the antimony dissolved as before. In the Syro-Palestine base glass, antimonate crystals again formed, but tended to be better dispersed with fewer clumps, giving the glass a more even opacity. Glassworker Mark Taylor (pers. com.) also described how adding lead oxide to white glass made the melt easier to work, by reducing its 'grittiness'. The presence of lead would therefore have been advantageous to glassworkers making opaque white glass, since it improved the workability of the glass, and probably the opacity by producing finer, better dispersed crystals. Lead oxide would also reduce the thermal expansion of the glass, and its viscosity and surface tension at a given temperature, which could assist during the making of cameo or other layered objects, where layers of different glass were adhering to one another. The increase in refractive index would make the glass appear glossier and a high lead content may have made the glass easier to cut.

For colourless glasses, particularly the Hellenistic variant that contained very low levels of stabilising calcium and aluminium oxides, added lead and antimony oxides may have played an important role in making the glass slightly easier to refine and work, as lead lowered the eutectic temperature of the melt. Although it may not have been obvious at the time, it probably also made the glass more durable, preserving these glasses for the archaeological record (Huisman et al. 2008).

A final consideration is that lead may have been combined with antimony in the late Hellenistic period as part of a process to prepare antimony minerals before adding them to the glass. Lead is used in refining because it oxidises easily, and then combines with other oxide phases. There is a long history of lead being calcined with either antimony or tin compounds (and sometimes both), often with fluxes and silica as well, in the production of pottery glazes, enamels, glasses and paint pigments from many periods. These lead-rich mixtures were

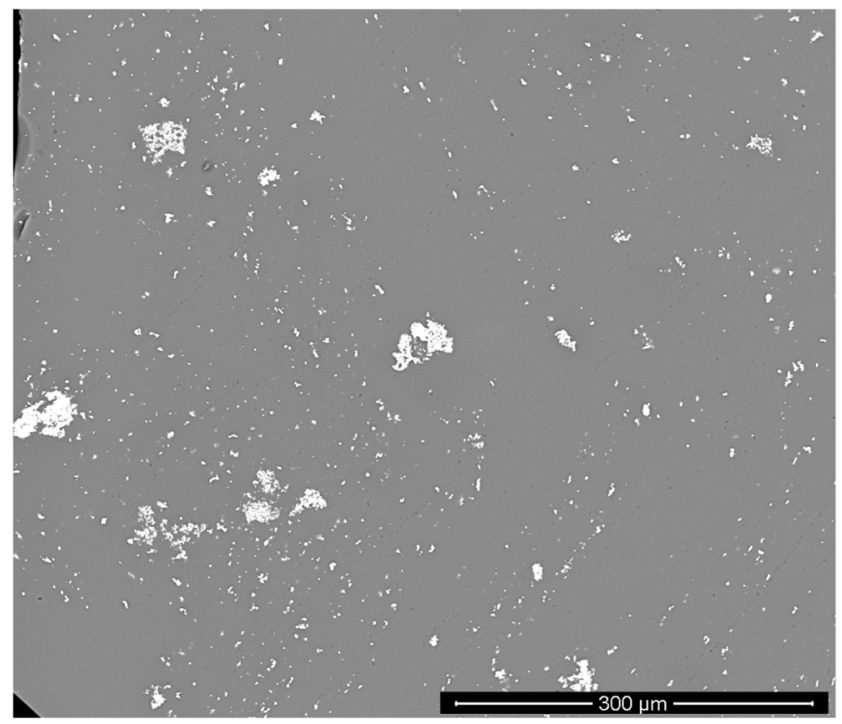

Fig. 9 SEM BSE image of experimental Syro-Palestine antimony opacified glass. The calcium antimonate crystals appear white in the images 
used mainly to make yellow pigments and opacifiers (Dik et al. 2005), as the yellow colour is due to lead antimonate and lead stannate. However lead is occasionally used in the preparation of white pigments too (Allan 1973; Paynter 2001, 373-390), even though the lead is not necessary for the white colour. Therefore the association of lead with antimony in late Hellenistic antimony colourless and opaque white, turquoise and blue glass may be due to the method of preparing antimony to make a white additive, but one that was used only for a limited period.

\section{Conclusions}

Compositional analysis of assemblages of Roman glass from sites in Britain compared with historical data, has illustrated the changing compositions of the antimony colourless glass reaching Western Europe at that time. Some of these changes have been attributed to production changes and others to recycling practices. This study highlights that the origins of the typical Roman antimony colourless glass can be traced back to developments in the later Hellenistic period, however analyses of Hellenistic antimony decolourised glass are lacking, and are key to better understanding the development of Roman antimony glass. The chronological analysis undertaken in this study is possible because many large assemblages of glass from Western Europe have been analysed using typological forms of known date. New experimental work has thrown light upon the division between different production centres for colourless glass, and their choice of decolorisers. Multiple key issues are highlighted:

\section{The composition of the natron base glass produced in} Egypt was ideally suited to the production of antimony decolourised glass. The high levels of sodium, combined with low levels of calcium and aluminium oxides, will readily dissolve several wt\% of antimony oxide, producing a brilliant, refined, colourless glass. In contrast, the contemporary glass made from the renowned glassmaking sand at the mouth of the Belus river in the SyroPalestine region, contains more calcium and less sodium, and with the same concentration of added antimony oxide, begins to form a calcium antimonate opacified glass. Therefore, the glass base composition had a bearing on what type of decolouriser, antimony or manganese, was preferred by different glass producers. Egyptian glassmakers, in proximity to the natron sources of the Wadi Natrun, could make a glass which was ideal for dissolving antimony.

2. The antimony used in late Hellenistic and Roman colourless glass, is a high quality, clean source. A high quality antimony source was important for colourless glass, to avoid adding contaminants accidentally with the decolouriser. The same is true of quality white glass. Therefore, although several sources of antimony were available to the ancient glassmaker, they were not necessarily all suitable to produce high quality colourless or white glass in their raw state. The antimony ores chosen for colourless glass may have been processed to remove contaminants, or selected from purer sources for certain applications.

3. The lead in late Hellenistic antimony colourless, and some white-opacified, glass may be an intentional addition to, rather than a contaminant of, the antimony mineral. Lead is present, in approximately the same ratio to antimony, in late Hellenistic antimony colourless glass analysed to date and some white-opacified glass, and may have been added intentionally to improve the properties of the glass, or as part of a process for preparing the antimony. The presence of lead in both white-opacified and antimony colourless glass in the same period raises the possibility that the lead-bearing antimony additive used initially as a decolouriser in antimony colourless glass may have been derived from the white opacifer used in contemporary opaque glass production, but added to a different base glass.

4. Recycling of antimony colourless glasses is apparent compositionally. The lead oxide (up to $0.6 \mathrm{wt} \%$ ) found in some 1st/2nd-century AD Roman antimony colourless glass is potentially the result of recycling late Hellenistic antimony colourless glass containing several weight percent of lead oxide. This late Hellenistic antimony colourless glass has been analysed rarely, in cast and facet-cut wares, but is likely to have been preferred when later glassworkers came to select cullet for making similar vessels. The addition of a small proportion to a glassworker's batch would result in significant lead contamination. The practice of adding lead to antimony for late Hellenistic colourless glass production appears to have been discontinued before the mid-1st century AD, but recycling would have ensured that some lead continued to be detected, particularly in 1st-century $\mathrm{AD}$ facet-cut wares.

5. The calcium content of antimony colourless glass is lowest in the late Hellenistic period and increases through the Roman period. This later glass is still transparent and colourless however, because at the same time the antimony content decreases, which may in part reflect difficulty obtaining a quality source of antimony towards the later Roman period (Jackson and Paynter 2015; Paynter and Jackson 2016). In addition, the increased demand for glassware as the empire grew, alongside an increase in the volume of production meant this resource had to be used more economically. After the 4 th century AD, glassmakers seek alternative types of decolorisers and 
opacifiers (Maltoni and Silvestri 2016; Turner and Rooksby 1959). It is at this point Egyptian glassmakers appear to have turned to manganese as a potential alternative to antimony, and HIMT glasses start to be produced.

\section{Implications for Roman glass technology}

Roman glassmakers had a breadth of expertise and raw materials at their disposal in an ever-expanding empire. The use of good quality sands and natron seems to have ensured that most Roman raw glasses had a low iron content, all theoretically suitable for producing colourless glass or a wide palette of colours. Yet there is considerable conservatism in the types of decolouriser used by different makers of Roman colourless glass, evidenced by the apparent preference for manganese in the Syro-Palestine furnaces and antimony in the Egyptian ones. Glassworkers were also discriminating between which base glass they chose when making opaque white glass.

The order in the edict of Diocletian for high quality colourless glass from Egypt gives it a higher value than other glass types, which might provide an incentive for other production centres to experiment with antimony decolourised glass, assuming that each had equal knowledge of, and access to, suitable antimony sources. However, this study indicates that subtle differences in the composition of the raw glass can have significant implications for the type of decolouriser that can be used, and that these limitations may be geographically specific. Glassmakers did not have a free choice, they were constrained in some ways by their environment and the raw materials they worked with.

Egyptian glasses were manufactured near the source of natron, and are higher in soda than their Syro-Palestinian counterparts. These high-sodium, low calcium/alumina glasses easily dissolved enough antimony to decolourise the glass. This relatively stable batch recipe would be ideal for making colourless glass in large quantities in the tank furnaces such as those seen at Beni Salama. In contrast, there would have been a high risk of calcium antimonate precipitating in the more calcium-rich, Syro-Palestinian glass recipe, particularly in the vast tank furnaces used for primary production, which cooled slowly over many days, encouraging crystallisation. Whilst the glassmakers could have increased the furnace temperature, or the proportion of imported natron in the batch, to try and counter this, both options would have had cost implications.

Conversely, Syro-Palestinian glasses were preferred for good quality opaque white glass, and Egyptian base glasses were often avoided, because the former would produce a more opaque glass with the same amount of antimony, which was probably the most expensive commodity. Opaque white glasses were produced at secondary centres, partly because opaque white glass was in less demand and so the quantities needed much smaller, but also because the degree and homogeneity of the opacity would be more easy to control in crucibles, where the temperature could be more closely controlled, than in large tanks. There are some parallels between antimony colourless glass and opaque white glass production though, as they appear to have made use of a similar antimony additive. In the late Hellenistic period, lead was probably added to this antimony additive, although later the lead was omitted.

Over time the composition of the Egyptian antimony colourless glass changes; the calcium content rises as they reduce the amount of antimony in the glass. This chronological change is apparent from the compositional data presented here because this study uses well-dated vessel forms, but the importance of recycling in interpreting these data cannot be underestimated. Recycling smears the compositions during transitional periods when glass recipes change, perhaps more so in archaeological material from north-western Europe where recycled glass was such a significant proportion of the glass in circulation (Jackson and Paynter forthcoming). Clearly, colourless glass was in demand and, even in the production of high quality vessels, recycled colourless glass was used.

The rise and decline of antimony colourless glass exemplifies many reoccurring trends in the history of early glass production. This glass is initially rare, due to the technological difficulty of making it, and used for high quality vessels in small quantities presumably for an elite market. By the Roman period, when this glass becomes more prevalent, the glassworkers' skill is demonstrated by their manipulation of different base glasses and decolourisers and recycled material to achieve the desired effects, whether opaque or colourless. In the 4th century AD when antimony supplies appear to diminish, they must also use their ingenuity to develop alternatives to the antimony-based additives that have been a mainstay of glassmaking for thousands of years. From beginning to end, colourless glass in all its brilliance reflects the economic and political changes of this time.

Acknowledgements We are grateful to The British Academy, NERC and Historic England/English Heritage for funding the initial analytical programmes and to the many museums and archaeological units who allowed us to sample their glass, as follows: Colchester Museum Service; English Heritage Midlands; City of Lincoln Archaeological Unit; York Archaeological Trust, Chester Archaeological Service; Royal Museum and Art Gallery, Canterbury; Museum of London; Winchester Museums Service, and Dr. A.K. Hands who provided material from Wilcote. We thank Beniot Disch and Kym Jarvis at the ICP-MS facility at Imperial College, London University, Ascot and NERC for supporting the trace element analysis (NERC OSS/340/0207). Thanks are also due to Jennifer Price, Sally Cottam, Sally Worrell, Mark Taylor, David Hill and Hilary Cool for their expertise and discussions along the way. We thank two anonymous referees for their detailed and constructive comments, which have been taken into full consideration. 
Open Access This article is distributed under the terms of the Creative Commons Attribution 4.0 International License (http:// creativecommons.org/licenses/by/4.0/), which permits unrestricted use, distribution, and reproduction in any medium, provided you give appropriate credit to the original author(s) and the source, provide a link to the Creative Commons license, and indicate if changes were made.

\section{References}

Allan J (1973) Abu'l-Qasim's treatise on ceramics. Iran 9:111-120

Anderson CG (2012) The metallurgyofantimony. Chem Erde 72(S4):3-8. https://doi.org/10.1016/j.chemer.2012.04.001

Barag D (1987) Recent important epigraphic discoveries related to the history of glassmaking in the Roman period. In: Annales de l'Association Internationale pour l'Histoire du Verre 10, Madrid and Segovia, 1985.109-116

Baxter MJ, Cool HEM, Jackson CM (2005) Further studies in the compositional variability of colourless Romano-British vessel glass. Archaeometry 47(1):47-68

Bertini M, Shortland A, Milek K, Krupp EM (2011) Investigation of iron age north-eastern Scottish glass beads using elementanalysis with LA-ICP-MS. J Archaeol Sci 38(10):2750-2766. https://doi.org/10. 1016/j.jas.2011.06.019

Bimson M, Freestone IC (1983) An analytical study of the relationship between the Portland-vase and other roman cameo glasses. J Glass Stud 25:55-64

Brems D, Degryse P (2014) Trace element analysis in provenancing Roman glass-making. Archaeometry 56(1):116-136. https://doi. org/10.1111/arcm.12063

Brems D, Degryse P, Hasendoncks F, Honings J (2012) Western Mediterranean sand deposits as raw material for Roman glass production. J Arch Sci 39(9):2897-2907. https://doi.org/10.1016/j.jas. 2012.03.009

Brill RH (1978) Some miniature glass plaques from Fort Shalmaneser, Nimrud. Part II: laboratory studies. Iraq 40(1):23-39. https://doi.org/ $10.2307 / 4200082$

Brill RH (1999) Chemical analyses of early glasses. Corning Museum of Glass, New York

Brill RH, Barnes IL (1994) Laboratory studies of some glasses from Vergina. J Glass Stud 36:11-23

Cool HEM and Jackson CM (2004) Roman vessel glass and glassworking waste. In: Dalwood H and Edwards R (eds) Excavations at Deansway, Worcester 1988-9. Romano-British small town to late medieval city, York. CBA Research Report 139.CBA, York, pp 439-449

Cool HEM and Price J (1995) Roman vessel glass from excavations in Colchester, 1971-1985. Colchester archaeological report 8. Colchester Archaeological Trust Ltd and English Heritage, Colchester

Dik J, Hermens E, Peschar R, Schenk H (2005) Early production recipes for lead antimonate yellow in Italian art. Archaeometry 47(3):593607. https://doi.org/10.1111/j.1475-4754.2005.00221.x

Eichholz DE (1962) Pliny, Natural History. Vol. X, books XXXVI and XXXVII, 153. Heinemann, London

Fontaine SD, Foy D (2007) L'épave Ouest-Embiez 1, Var : le commerce maritime du verre brut et manufacturé enMéditerranée occidentale dans l'Antiquité. Revue Archéologique de Narbonnaise 40(1):235265. https://doi.org/10.3406/ran.2007.1182

Foster H, Jackson CM (2005) A whiter shade of pale'? Chemical and experimental investigation of opaque white Roman glass gaming counters. Glass Technol 46:327-333

Foy D, Vichy M and Picon M (2000) L'ingots de verre en Méditerranée occidentale (IIIe siècle av. J.-C. -VIIe siècle ap. J.-C.). In: Annales $\mathrm{du} 14 \mathrm{e}$ Congrès de l'Association Internationale pour l'Histoire de Verre: Italia/Venezia-Milano.AIHV, Amsterdam, pp 51-57
Foy D, Picon M, Thirion-Merle V and Vichy M (2003) Caractérisation des verres de lafin de l'Antiquité en Méditerranée occidentale: l'émergence de nouveaux courants commerciaux. In:Echanges et commerce du verre dans le monde antique, actes du colloque de l'AFAV, Aix-en-Provence, Juin 2001. Instrumentum, Montagnac, pp 41-85

Foy D, Thirion-Merle V, Vichy M (2004) Contribution à l'étude des verres antiques décolorés a l'antimoine. Revue d'Archéométrie 28:169-177

Freestone I, Stapleton CP (2015) Composition technology and production of coloured glasses from Roman mosaic vessels. In: Bayley J, Freestone I, Jackson C (eds) Glass of the roman world. Oxbow, Oxford, pp 61-76

Galili E, Gorin-Rosen Y and Rosen B (2015) Mediterranean coasts, cargoes of raw glass. Hadashot Arkheologiyot, excavations and surveys in Israel. http://www.hadashot-esi.org.il/report_detail_eng. aspx?id=24846\&mag id=122 (consulted 3/3/2017)

Ganio M, Boyen S, Brems D, Scott R, Foy D, Latruwe K, Molin G, Silvestri A, Vanhaecke F, Degryse P (2012) Trade routes across the Mediterranean: a $\mathrm{Sr} / \mathrm{Nd}$ isotopic investigation on roman colourless glass. Proceedings of the international conference on chemistry of glasses and glass-forming melts, Oxford UK September 2011. Glass Technol Eur J Glass Sci Technol A 53(5):217-224

Gliozzo E (2017) The composition of colourless glass: a review. Archeol Anthropol Sci 9(4):455-483. https://doi.org/10.1007/s12520-0160388-y

Henderson J (1991) Industrial specialization in late iron age Britain and Europe. Archaeol J 148(1):104-148

Henderson J (2013) Ancient glass: an interdisciplinary exploration. Cambridge

Heyworth MP, Baxter MJ and Cool HEM (1990) Compositional analysis of Roman glass from Colchester, Essex. Ancient monuments laboratory reports, 53/90

Huisman DJ, Pols S, Joosten I, Van Os BJH, Smit A (2008) Degradation processes in colourless Roman glass: cases from the Bocholtz burial. J Archaeol Sci 35(2):398-411. https://doi.org/10.1016/j.jas.2007.04.008

Huisman DJ, De Groot T, Pols S, van Os BJH, Degryse P (2009) Roman glass objects from the Bocholtz burial (the Netherlands). Archaeometry 51(3):413-439. https://doi.org/10.1111/j.1475-4754.2008.00401.x

Ignatiadou D (2000) Three cast-glass vessels from a Macedonian tomb in Pydna. In: AIHV annales du 14e congrès de l'Association Internationale pour l'Histoire du verre, pp 35-38

Jackson CM (2005) Making colourless glass in the Roman period. Archaeometry 47(4):763-780

Jackson CM, Nicholson PT (2010) The provenance of some glass ingots from the Uluburun shipwreck. J Arch Sci 37:295-301

Jackson CM, Paynter S (2015) A great big melting pot: exploring patterns of glass supply, consumption and recycling in Roman Coppergate, York. Archaeometry 58(1):68-95. https://doi.org/10.1111/arcm.12158

Jackson CM and Paynter S (forthcoming) Living on the edge: The secondary glass industry in Roman Britain.

Jackson CM, Smedley JW (2004) Medieval and post-medieval glass technology: melting characteristics of some glasses melted from vegetable ash and sand mixtures. Glass Technol 45(1):36-42

Jackson CM, Wager EC, Joyner L, Day PM, Booth CA, Kilikoglou V (2003) Small-scale glass making at Coppergate, York: analytical evidence for the nature of production. Archaeometry 45(3):435456. https://doi.org/10.1111/1475-4754.00120

Jackson CM, Paynter S, Nenna M-D, Degyrse P (2016) Glassmaking using natron from el-Barnugi (Egypt); Pliny and the Roman glass industry. Archaeol Anthropol Sci. https://doi.org/10.1007/s12520016-0447-4

Kowatli I, Curvers HH, Stuart B, Saberolles Y, Henderson J, Reynolds P (2008) A pottery and glassmaking site in Beirut (015). Bulletin de Archéologie et d'Architecture Libanaises 10:103-120

Licenziati F and Calligaro T (2015) Study of mosaic glass tesserae from Delos, Greece using a combination of portable $\mu$-Raman and X-ray fluorescence spectrometry. J Archaeol Sci, Reports 
Maltoni S, Silvestri A (2016) Innovation and tradition in the fourth century mosaic of the casa delle Bestie Ferite in Aquileia, Italy: archaeometric characterisation of the glass tesserae. Archaeol Anthropol Sci. https://doi.org/10.1007/s12520-016-0359-3

Mass JL, Stone RE, Wypyski MT (1998) The mineralogical and metallurgical origins of roman opaque colored glasses. In: Kingery WD, McCray P (eds) Ceramics and civilization 8. The American ceramic society, Westerville, pp 121-144

Mommsen H, Bruning A, Dittmann H, Hein A, Rosenberg A, Sarrazin G (1997) Recent investigations of early roman cameo glass. Part 2. Xray fluorescence analyses induced by synchrotron radiation. Glass SciTech 70:211-219

Mortimer C, and Baxter MJ (1996) Analysis of Samples of Colourless Roman Vessel Glass from Lincoln, Ancient Monuments Laboratory Report 44/96

Nenna M-D (2015) Primary glass workshops in Graeco-Roman Egypt: preliminary report on the excavations of the site of Beni-Salama, Wadi Natrun (2003, 2005-2009). In: Bayley J, Freestone IC, Jackson CM (eds) Glass of the roman Empire. Oxbow, Oxford

Nenna M-D, Vichy M, Picon M (1997) L'Atelier de verrier de Lyon, du ler siècle après J.-C., et l'origine des verres 'Romains'. Revue d'Archéométrie 21:81-87

Nenna M.-D, Picon M, Thirion-Merle V and Vichy M (2005)Ateliers primaires du Wadi Natrun: nouvelles découvertes Annales du 16e Congrès de l'AIHV, pp 59-63

Paynter S (2001) The development of vitreous materials in the ancient near east and Egypt (unpublished DPhil thesis). University of Oxford, Oxford

Paynter S (2006) Analyses of colourless Roman glass from Binchester, County Durham. J Arch Sci 33:1037-1057

Paynter S, Jackson CM (2016) Re-used roman rubbish: a thousand years of recycling glass. Post-Classical Archaeol 6:31-52

Paynter S, Kearns T, Cool H, Chenery S (2015) Roman coloured glass in the western provinces: the glass cakes and tesserae from west Clacton in England. J Archaeol Sci 62:66-81. https://doi.org/10. 1016/j.jas.2015.07.006

Pearce NJG, Perkins WT, Westgate JA, Gorton MP, Jackson SE, Neal CR, Chenery SP (1997) A compilation of new and published major and trace element data for NIST SRM 610 and NIST SRM 612 glass reference materials. Geostandards Newsletter. J Geostandards Geoanal 21(1):115-144

Picon M, Thirion-Merle V and Vichy M (2008) Les verres au natron et les verres aux cendres du Wadi Natrun (Egypte). Bulletin de l'Association Française pour l'Archéologie du Verre, pp 36-41

Price J, Cool HEM (1991) The evidence for the production of glass in roman Britain. In: Foy D, Sennequier G (eds) Ateliers de Verriers de l'Antiquité à la période préindustrielle. Association Française pour l'Archéologie du Verre, Rouen, pp 23-30

Price J and Cottam S (1998) Romano-British glass vessels: a handbook. Practical handbooks in archaeology no 14. CBA, York

Price J, Worrell S (2010) The glass. In: Ferris I (ed) The beautiful rooms are empty: excavations at Binchester roman fort, 1976-1981 and 1986-1991. Durham County Council, Durham, pp 268-332

Reade W, Privat K (2016) Chemical characterisation of archaeological glasses from the Hellenistic site of Jebel Khalid, Syria by electron probe microanalysis. Heritage Sci 4(1):1-17
Rehren Th, Spenser L and Triantafyllidis P (2005) The primary production of glass at Hellenistic Rhodes. In: Annalesdu16eCongrèsdel'Association Internationale pour l' Histoire du Verre, London 2003. International Association for the History of Glass, Nottingham, pp 39-43

Sayre EV (1963) The intentional use of antimony and manganese in ancient glasses. In: Matson FR and Rindone GE (eds) Advances in glass technology: history papers and discussions of the technical papers. Plenum Press, pp 263-282

Sayre EV, Smith RW (1961) Compositional categories of ancient glass. Science 133(3467):1824-1826. https://doi.org/10.1126/science. 133.3467.1824

Shortland A (2002) The use and origin of antimonate colorants in early Egyptian glass. Archaeometry 44(4):517-530. https://doi.org/10. $1111 / 1475-4754.00083$

Silvestri A (2008) The coloured glass of the Iulia Felix. J Arch Sci 35: $1489-1501$

Silvestri A, Molin G, Salviulo G, Schievenin R (2006) Sand for roman glass production: an experimental and philological study on source of supply. Archaeometry 48(3):415-432. https://doi.org/10.1111/j. 1475-4754.2006.00264.x

Silvestri A, Molin G, Salviulo G (2008) The colourless glass of Iulia Felix. J Archaeol Sci 35:331-341

Stern M (1991) Early exports beyond the empire. In: roman glass. Two centuries of art and invention. Society antiquaries London, occasional papers 13. London, pp 141-154

Thirion-Merle V, Vichy M (2007) Note sur la composition chimique des verres de l'épave des Embiez. In: Revuearchéologique de Narbonnaise 40:266-268

Thirion-Merle V, Nenna M-D, Picon M, Vichy M (2002-2003) Un nouvel atelier primaire dans le Wadi Natrun (Egypte) et les compositions des verres produits dans cette région. Bulletin de l'AFAV, Dijon, pp 21-24

Triantafyllidis P (2000) New evidence of the glass manufacture in classical and Hellenistic Rhodes. In: Annales du 14e Congrès de l'Association Internationale pour l' Histoire du Verre: Venezia Milano 1998. Lochem, 30-34

Turner WES (1956) Studies in ancient glasses and glassmaking processes; part V, raw materials and melting processes. Glass Technol 40:277-300

Turner WES, Rooksby HP (1959) A study of the opalising agents in ancient glasses throughout three thousand four hundred years. Glastechnische Berichte 8:17-28

Vallotto M and Verità M (2000) Glasses from Pompeii and Herculaneum and the sands of the river Belus and Volturno. In: Homo Faber: studies on nature, technology, and science at the time of Pompeii, Munich

Venclová N, Hulínský V, Jonášová Š, Frána J, Fikrle M, Vaculovič T (2015) Hellenistic mosaic glass vessels in bohemia and Moravia. Archeologické Rozhledy 67(2):213-238

Vichy M (2000) Ateliers primaires et secondaires en Égypte à l'époque gréco-romaine. La Route du Verre, Travaux de la Maison d'Orient Méditerranéen 33:97-112

Wedepohl KH (1995) The composition of the continental crust. Geochimica et Cosmochimica Acta 59:1217-1232

Whitehouse D (1991) Cameo glass. In: Newby M, Painter KS (eds) Roman glass: two centuries of art and invention. Society of Antiquaries of London, London, pp 19-32

Whitehouse D (1997) Roman glass in the corning Museum of Glass. Corning, New York 